\title{
Highly Active Binuclear Neutral Nickel(II) Catalysts Affording High Molecular Weight Polyethylene
}

\author{
Peter Wehrmann and Stefan Mecking* \\ Lehrstuhl für Chemische Materialwissenschaft, Fachbereich Chemie, Universität Konstanz, \\ Universitätsstrasse 10, D-78457 Konstanz, Germany
}

\begin{abstract}
A series of new binuclear neutral $\kappa^{2}-\mathrm{N}, \mathrm{O}-$ chelated $\mathrm{Ni}(\mathrm{II})$ complexes $\left[\left(\mathrm{H}_{2} \mathrm{C}\right)_{n}\left\{\left[\left(2,6-\mathrm{R}_{2}-4-\mathrm{yl}-\mathrm{C}_{6} \mathrm{H}_{2}\right)-\right.\right.\right.$ $\left.\mathrm{N}=\mathrm{C}(\mathrm{H})-\left(3,5-\mathrm{I}_{2}-2-\mathrm{O}-\mathrm{C}_{6} \mathrm{H}_{2}\right)-\kappa^{2}-N, O\right] \mathrm{Ni}\left(\mathrm{CH}_{3}\right)($ pyridine $\left.\left.)\right\}_{2}\right]\left(\mathrm{R}=i \mathrm{Pr}, 3,5-\left(\mathrm{CF}_{3}\right)_{2} \mathrm{C}_{6} \mathrm{H}_{3} ; n=0,1\right)$ are reported. The complexes are single-component catalyst precursors for ethylene polymerization. Catalyst activities exceed those of mononuclear analogues studied substantially. With $3.4 \times 10^{5} \mathrm{TO} \mathrm{h}^{-1}$, high molecular weight polymer is obtained $\left(M_{\mathrm{w}} 9.2 \times 10^{5} \mathrm{~g} \mathrm{~mol}^{-1} ; M_{\mathrm{n}} 2.8 \times 10^{5} \mathrm{~g} \mathrm{~mol}^{-1}\right)$. Semicrystalline polyethylene with a low degree of branching is formed ( 2 to 12 branches/1000 carbon atoms; prepared at 30 to $70{ }^{\circ} \mathrm{C}$ polymerization temperature), with $T_{\mathrm{m}} 112$ to $136{ }^{\circ} \mathrm{C}$. Polymerization in aqueous emulsion affords polyethylene dispersions.
\end{abstract}

\section{Introduction}

Olefin polymerization by cationic complexes of $\mathrm{d}^{8}$ metals (late transition metals) has been studied intensely in the past decade. ${ }^{1}$ Due to their functional group tolerance, ethylene and 1-olefins can be copolymerized with polar monomers such as acrylates. ${ }^{2}$ Substantial branching, and unique branching patterns can be introduced in ethylene homopolymerization. ${ }^{3,4}$ These studies prompted renewed interest in neutral nickel(II) ethylene polymerization catalysts. ${ }^{5,6}$ By comparison to their cationic $\mathrm{Ni}$ (II) counterparts, they are more tolerant toward polar reagents. Thus, polymerization can be carried out in aqueous emulsion to afford polyolefin dispersions. ${ }^{7-9}$ There is a strong interest in the discovery of more active neutral $\mathrm{Ni}$ (II) polymerization catalysts that polymerize ethylene to high molecular weight polymer. As a guideline for accessing high molecular weight $\left(M_{\mathrm{n}}\right)$ polymer,

* Corresponding author. E-mail: stefan.mecking@uni-konstanz.de.

(1) (a) Ittel, S. D.; Johnson, L. K.; Brookhart, M. Chem. Rev. 2000, 100, 1169-1203. (b) Gibson, V. C.; Spitzmesser, S. K. Chem. Rev. 2003, 103, 283-316. (c) Mecking, S. Angew. Chem Int. Ed. 2001, 40, 534-540. (d) Mecking, S. Coord. Chem. Rev. 2000, 203, 325-351. (e) Berkefeld, A.; Mecking, S. Angew. Chem. Int. Ed. 2008, in press.

(2) (a) Johnson, L. K.; Mecking, S.; Brookhart, M. J. Am. Chem. Soc. 1996, 118, 267-268. (b) Mecking, S.; Johnson, L. K.; Wang, L.; Brookhart, M. J. Am. Chem. Soc. 1998, 120, 888-899. (c) Johnson, L. K.; McLain, S. J.; Sweetman, K. J.; Wang Y.; Bennett, A. M. A.; Wang, L.; McCord, E. F.; Lonkin, A.; Ittel, S. D.; Radzewich, C. E.; Schiffino, R. S. (Du Pont) WO2003044066, 2003. (d) Johnson, L.; Wang, L.; McLain, S.; Bennett, A.; Dobbs, K.; Hauptman, E.; Ionkin, A.; Ittel, S.; Kunitsky, K.; Marshall, W.; McCord, E.; Radzewich, C.; Rinehart, A.; Sweetman, K. J.; Wang, Y.; Yin, Z.; Brookhart, M. ACS Symp. Ser. 2003, 857, 131-142. (e) Li, W.; Zhang, X.; Meetsma, A.; Hessen, B. J. Am. Chem. Soc. 2004, 126, 12246 12247. (f) Chen, G.; Guan, Z. J. Am. Chem. Soc. 2004, 126, 2662-2663. (g) Luo, S.; Jordan, R. F. J. Am. Chem. Soc. 2006, 128, 12072-12073 Also cf.: (h) Drent, E.; van Dijk, R.; van Ginkel, R.; van Oort, B.; Pugh, R. I. Chem. Commun. 2002, 744-745.

(3) (a) Killian, M. C.; Johnson, L. K.; Brookhart, M. J. Am. Chem. Soc. 1995, 117, 6414-6415. (b) Guan, Z.; Cotts, P. M.; McCord, E. F.; McLain, S. J. Science 1999, 283, 2059-2062.

(4) For an earlier example of a nickel(II) complex producing branched, low molecular weight ethylene homopolymer see: Keim, W.; Appel, R.; Storeck, A.; Krüger, C.; Goddard, R. Angew. Chem., Int. Ed. Engl. 1981, 20, 116-117. (b) Keim, W. Ann. N.Y. Acad. Sci. 1983, 415, 191-200. Also cf.: (c) Moehring, V. M.; Fink, G. Angew. Chem., Int. Ed. Engl. 1985, 24, 1001-3. (d) Stapleton, R. A.; Chai, J.; Nuanthanom, A.; Flisak, Z.; Nele, M.; Ziegler, T.; Rinaldi, P. L.; Soares, J. B. P.; Collins, S. Macromolecules 2007, 40, 2993-3004. by analogy to ethylene polymerization by cationic diimine complexes, which have been studied in much detail mechanistically, bulky substituents are considered to retard chain transfer by blocking the axial positions on the metal center. Concerning catalyst activity, an order of magnitude difference in polymerization activity corresponds to a difference in the overall

(5) (a) Wang, C.; Friedrich, S.; Younkin, T. R.; Li, R. T.; Grubbs, R. H.; Bansleben, D. A.; Day, M. W. Organometallics 1998, 17, 3149-3151. (b) Johnson, L. K.; Bennett, A. M. A.; Ittel, S. D.; Wang, L.; Parthasarathy, A.; Hauptman, E.; Simpson, R. D.; Feldman, J.; Coughlin, E. B. (DuPont) WO98/30609, 1998. (c) Younkin, T. R.; Connor, E. F.; Henderson, J. I.; Friedrich, S. K.; Grubbs, R. H.; Bansleben, D. A. Science 2000, 287, 460462. (d) Hicks, F. A.; Brookhart, M. Organometallics 2001, 20, 32173219. (e) Soula, R.; Broyer, J. P.; Llauro, M. F.; Tomov, A.; Spitz, R.; Claverie, J.; Drujon, X.; Malinge, J.; Saudemont, T. Macromolecules 2001, 34, 2438-42. (f) Gibson, V. C.; Tomov, A.; White, A. J. P.; Williams, D. J. Chem. Commun. 2001, 719-20. (g) Zuideveld, M.; Wehrmann, P.; Röhr, C.; Mecking, S. Angew. Chem., Int. Ed. 2004, 43, 869-873. (h) Jenkins, J. C.; Brookhart, M. J. Am. Chem. Soc. 2004, 126, 5827-5842. (j) Zhang, L.; Brookhart, M.; White, P. S. Organometallics 2006, 25, 1868-1874. (k) Kuhn, P.; Sémeril, D.; Jeunesse, C.; Matt, D.; Neuburger, M.; Mota, A. Chem.-Eur. J. 2006, 12, 5210-5219. (1) Göttker-Schnetmann, I.; Wehrmann, P.; Röhr, C.; Mecking, S. Organometallics 2007, 26, 2348-2362. (m) Yu, S.-M.; Berkefeld, A.; Göttker-Schnetmann, I.; Müller, G ; Mecking, S. Macromolecules 2007, 40, 421-428. (n) Bastero, A.; Göttker-Schnetmann, I.; Röhr, C.; Mecking, S. Adv. Synth. Catal. 2007, 349, 2307-2316.

(6) Early work: Keim, W.; Kowaldt, F. H.; Goddard, R.; Krüger, C. Angew. Chem., Int. Ed. Engl. 1978, 17, 466-467. (b) Ostoja Starzewski, K. A.; Witte, J. Angew. Chem., Int. Ed. Engl. 1985, 24, 599-601. (c) Klabunde, U.; Ittel, S. D. J. Mol. Catal. 1987, 41, 123-134.

(7) (a) Held, A.; Bauers, F. M.; Mecking, S. Chem. Commun. 2000, 301-302. (b) Bauers, F. M.; Mecking, S. Macromolecules 2001, 34, 11651171. (c) Bauers, F. M.; Mecking, S. Angew. Chem., Int. Ed. 2001, 40, 3020-3022. (d) Bauers, F. M.; Chowdhry, M. M.; Mecking, S. Macromolecules 2003, 36, 6711-6715. (e) Bauers, F. M.; Thomann, R.; Mecking, S. J. Am. Chem. Soc. 2003, 125, 8838-8840. (f) Kolb, L.; Monteil, V.; Thomann, R.; Mecking, S. Angew. Chem., Int. Ed. 2005, 44, 429-432. (g) Wehrmann, P.; Mecking, S. Macromolecules 2006, 39, 5963-5964. (h) Wehrmann, P.; Zuideveld, M. A.; Thomann, R.; Mecking, S. Macromolecules 2006, 39, 5995-6002. (j) Göttker-Schnetmann, I.; Korthals, B.; Mecking, S. J. Am. Chem. Soc. 2006, 128, 7708-7709. (k) Weber, C. H. M.; Chiche, A.; Krausch, G.; Rosenfeldt, S.; Ballauf, M.; Harnau, L.; GöttkerSchnetmann, I.; Tong, Q.; Mecking, S. Nano Lett. 2007, 7, 2024-2029.

(8) (a) Tomov, A.; Broyer, J.-P.; Spitz, R. Macromol. Symp. 2000, 150, 53-58. (b) Soula, R.; Novat, C.; Tomov, A.; Spitz, R.; Claverie, J.; Drujon, X.; Malinge, J.; Saudemont, T. Macromolecules 2001, 34, 2022-2026. (c) Soula, R.;Saillard, B.;Spitz, R.;Claverie, J.;Llaurro, M. F.; Monnet, CMacromolecules2002, 35, 1513-1523. 
activation energy of chain growth of 1-2 kcal. This may be brought about by subtle changes of the catalyst structure.

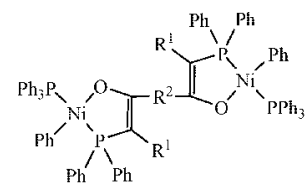

$1: \mathrm{R}_{1}=\mathrm{H}, \mathrm{Ph}, \mathrm{Mc}, \mathrm{Na}^{\prime}-\mathrm{O}_{3} \mathrm{~S}, \mathrm{CO}_{2} \mathrm{Mc}$ $\mathrm{R}_{2}=\left(\mathrm{CH}_{2}\right)_{4-8}, \mathrm{C}_{6} \mathrm{H}_{4}, 1, \mathrm{I}^{\prime}-\left(\eta^{5}-\mathrm{C}_{5} \mathrm{H}_{4}\right)_{2} \mathrm{Fe}, \Leftarrow$

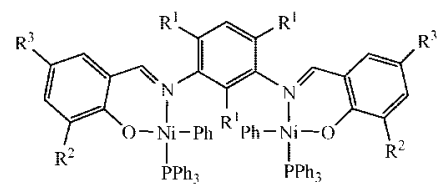

$$
\begin{array}{rlrl}
\text { 3: } \mathrm{R}^{\mathrm{l}} & =\mathrm{Me} & \text { 4: } \mathrm{R}^{\mathrm{l}}={ }^{\mathrm{i}} \mathrm{Pr}, \mathrm{Me}, \mathrm{Et} \\
\mathrm{R}^{2} & ={ }^{\mathrm{t}} \mathrm{Bu}, \mathrm{Ph} & \mathrm{R}^{2} & =\mathrm{H}, \mathrm{Me},{ }^{\mathrm{t}} \mathrm{Bu}, \mathrm{Ph}_{,} \mathrm{NO}_{2} \\
\mathrm{R}^{3} & =\mathrm{H}, \mathrm{Me} & \mathrm{R}^{3} & =\mathrm{H}_{2} \mathrm{NO}_{2}
\end{array}
$$

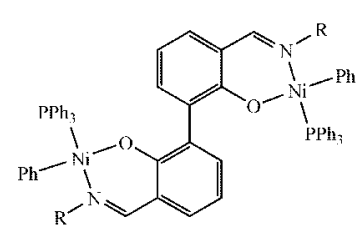

5: $\mathrm{R}=2,6-\mathrm{Pr}_{2} \mathrm{C}_{6} \mathrm{H}_{3}$

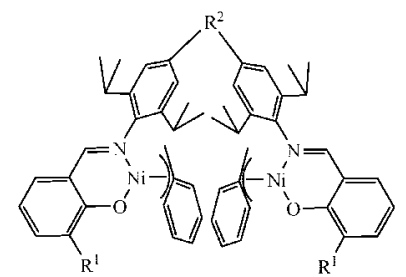

6: $\mathrm{R}^{\mathrm{l}}=9$-Anthryl $\mathrm{R}^{2}=\mathrm{CH}_{2}, \mathrm{o}-\mathrm{C}_{6} \mathrm{H}_{4}, \mathrm{O}-\mathrm{C}_{6} \mathrm{H}_{4}\left(\mathrm{C}_{6} \mathrm{H}_{4}\right)_{2}$
Ethylene polymerization with binuclear phosphinoenolate complexes 1 as catalyst precursors was studied. ${ }^{10}$ Activities of up to $1.8 \times 10^{5} \mathrm{TO} \mathrm{h}^{-1}$ were observed, which is higher than that of analogous mononuclear complexes. As with mononuclear $\mathrm{Ni}(\mathrm{II})$ phosphinoenolate complexes, number average molecular weights are rather low $\left(M_{\mathrm{n}} \approx 1 \times 10^{4} \mathrm{~g} \mathrm{~mol}^{-1}\right)$, and activation by a phosphine scavenger is required for these polymerizations. Complexes 2, derived from 2,5-disubstituted amino- $p$-benzoqinones, polymerize ethylene with catalyst activities around 6 $\times 10^{3} \mathrm{TO} \mathrm{h}^{-1}$ and afford polyethylene with a molecular weight of up to $M_{\mathrm{n}}=1.3 \times 10^{5} \mathrm{~g} \mathrm{~mol}^{-1} \cdot{ }^{11}$ Salicylaldiminato complexes 3 and 4, with a bridging moiety derived from 2,4,6-trialkyl-mphenylene diamines, were reported recently. ${ }^{12,13}$ By comparison to an analogous mononuclear complex investigated, a slightly higher molecular weight and broader molecular weight distribution were found $\left(M_{\mathrm{n}}=2.3 \times 10^{4} \mathrm{~g} \mathrm{~mol}^{-1} ; M_{\mathrm{w}} / M_{\mathrm{n}}=6.1\right.$; for 3, $\left.\mathrm{R}^{1}=\mathrm{Me}, \mathrm{R}^{2}=\mathrm{Ph} \mathrm{R}^{3}=\mathrm{H}\right)$. In mononuclear $\mathrm{Ni}(\mathrm{II})$ salicylaldiminato complexes, bulky substituents in 2-position of the phenolate moiety enhance polymerization activity and facilitate phosphine dissociation, which is a prerequisite for formation of the active catalyst. ${ }^{5 c}$ In the binuclear 5 , the phenolate moiety coordinating the other metal center, respectively, serves this purpose. ${ }^{14}$ In contrast to the unsubstituted mononuclear analogue, these binuclear complexes are active for ethylene polymerization without any added phosphine scavenger, with an activity of ca. $1.6 \times 10^{4} \mathrm{TO} \mathrm{h}^{-1}$. In 6 , the

(9) (a) Reviews: Mecking, S.; Held, A.; Bauers, F. M. Angew. Chem. Int. Ed. Engl. 2002, 41, 544-561. (b) Mecking, S.; Claverie, J. In Late Transition Metal Polymerization Catalysis; Rieger, B.; Baugh, L. S.; Kacker, S., Striegler, S., Eds.; Wiley-VCH: Weinheim, 2003; pp 231-278. (c) Claverie, J. P.; Soula, R. Prog. Polym. Sci. 2003, 28, 619-662. (d) Mecking, S. Colloid Polym. Sci. 2007, 285, 605-619.

(10) Kurtev, K.; Tomov, A. J. Mol. Catal. 1994, 88, 141-150.

(11) Zhang, D.; Jin, G.-X. Organometallics 2003, 22, 2851-2854.

(12) Zhang, D.; Jin, G.-X. Inorg. Chem. Commun. 2006, 9, 1322-1325.

(13) Chen, Q.; Yu, J.; Huang, J. Organometallics 2007, 26, 617-625.

(14) Hu, T.; Tang, L.-M.; Li, X.-F.; Li, Y.-S.; Hu, N.-H. Organometallics 2005, 24, 2628-2632. salicylaldiminato moieties are bridged via the $p$-position of the $\mathrm{N}$-aryls. ${ }^{15}$ An anthryl substituent in the 3-position of the phenolate moiety, the introduction of which in the salicylaldehyde employed for salicylaldimine synthesis requires some synthetic effort, provides steric bulk. The nature and geometry of the bridge $\left(\mathrm{R}^{2}\right)$ has a profound effect on the catalytic properties. In copolymerizations of ethylene with polarsubstituted norbornenes, the binuclear complexes incorporate a significantly larger portion of the norbornene derivative. This is suggested to be the result of a prearrangement of the polar comonomer by interaction of its polar functional group with the second metal center. In ethylene polymerization, no substantial difference was observed between mono- and binuclear complexes; ethylene is converted with $7 \times 10^{4} \mathrm{TO}^{-1}$ to $10^{5}$ $\mathrm{TO}^{-1}$ (in experiments of 5 to $10 \mathrm{~min}$ total duration).

We report a series of conveniently accessible novel binuclear salicylaldiminato nickel(II) methyl complexes, which polymerize ethylene to high molecular weight polymer with high catalyst activities at the same time, and polymerization in aqueous systems with these complexes.

\section{Results and Discussion}

Ligands and Complexes. Anilines and Salicylaldimines. Tetraisopropylbenzidine (7a) was prepared from 2,6-diisopropylaniline by bromination to afford 4-bromo-2,6-diisopropylaniline ( $97 \%$ yield) and palladium-catalyzed oxidative coupling of the latter to afford 7a in $40 \%$ yield as pinkish crystals (eq 1). ${ }^{16}$

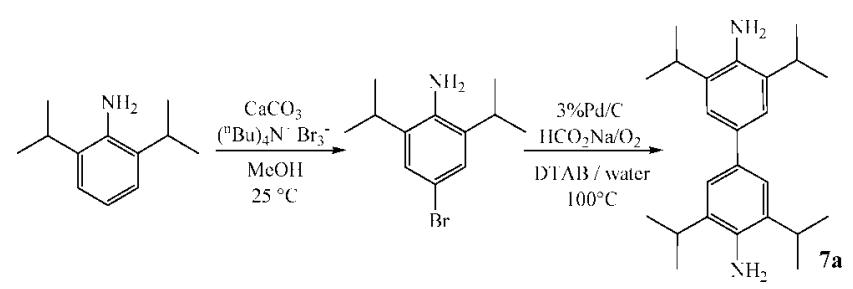

(1)

4,4'-Diamino-2,2',6,6'-tetraisopropyldiphenylmethane (7b) was commercially available.

For the preparation of di(terphenylanilines) $\mathbf{8 a}$ and $\mathbf{8 b}$ (eq 2 ), the bromides tetrabromobenzidine and $4,4^{\prime}$-diamino- $2,2^{\prime}, 6,6^{\prime}$ tetrabromodiphenylmethane were prepared by bromination of benzidine and 4,4'-diaminodiphenylmethane with tetra- $n$-butylammonium tribromide (63\% and $82 \%$ yield, respectively). Suzuki coupling with 3,5-bis(trifluoromethyl)phenylboronic acid afforded $\mathbf{8 a}$ and $\mathbf{8 b}$ (74\% and $95 \%$ yield, respectively).

2,4,6-Tris[3,5-bis(trifluoromethyl)phenyl]aniline (9) was obtained analogously by Suzuki coupling of 2,4,6-tribromo aniline with the boronic acid.

Salicylaldimines (10 to 12) were obtained from the above anilines and 3,5-diiodosalicylaldehyde by condensation in toluene with azeotropic removal of water. The crude products obtained upon solvent evaporation were recrystallized from dry methanol.

The salicylaldimines and anilines were characterized by ${ }^{1} \mathrm{H}$ and ${ }^{13} \mathrm{C}\left\{{ }^{1} \mathrm{H}\right\}$ NMR spectroscopy. Resonances were assigned completely by two-dimensional NMR experiments (COSY, ROESY, HSQC, HMBC). The compounds are pure by elemental analysis.

(15) S, S.; Joe, D. J.; Na, S. J.; Park, Y.-W.; Choi, C. H.; Lee, B. Y. Macromolecules 2005, 38, 10027-33.

(16) Bamfield, P.; Quan, P. M. Synthesis 1978, 7, 537-538. 


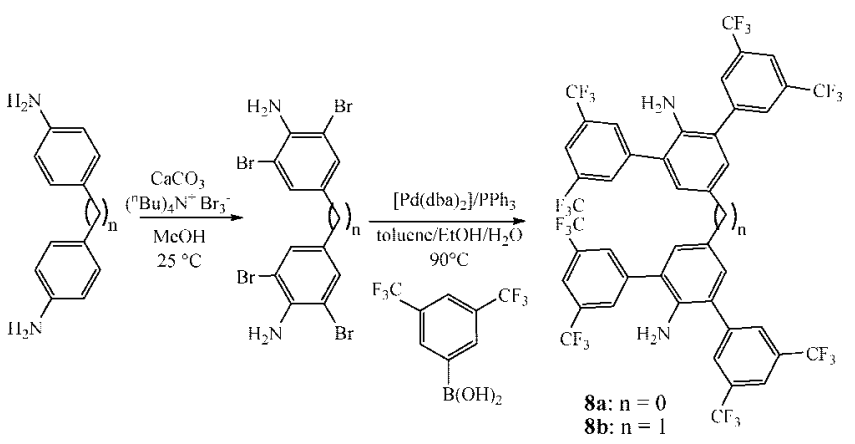

(2)

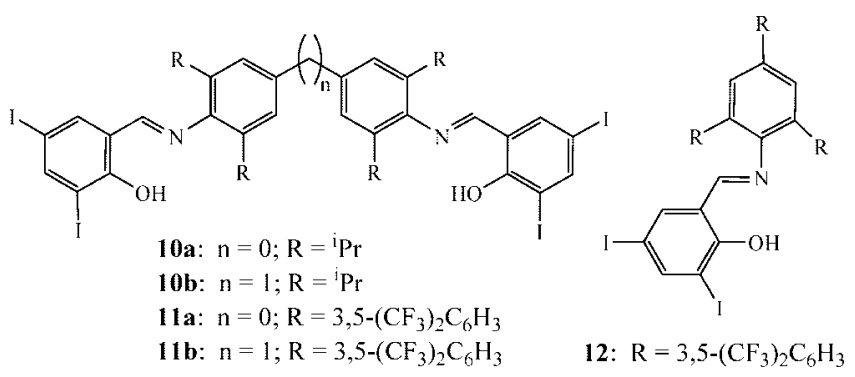

Complexes. The binuclear salicylaldiminato Ni(II) methylpyridine complexes 13a and $\mathbf{1 4 a}, \mathbf{b}$ were prepared by reaction of the salicylaldimines with [(pyridine $\left.)_{2} \mathrm{NiMe}_{2}\right]$ at $-30{ }^{\circ} \mathrm{C}$ in $\mathrm{Et}_{2} \mathrm{O}$. One metal-bound methyl group per $\mathrm{Ni}(\mathrm{II})$ center is expelled as methane. The crystalline, orange to red compounds were isolated in $80 \%$ to $90 \%$ yield. As an alternative nickel source, [(tmeda) $\mathrm{NiMe}_{2}$ ] was employed in the synthesis of $\mathbf{1 3 b}$, with added pyridine in toluene as a solvent at $-30{ }^{\circ} \mathrm{C}$. 13b was isolated in $90 \%$ yield (for a comparison of [(pyridine) $2_{2}$ $\mathrm{NiMe}_{2}$ ] and [(tmeda)NiMe $\mathrm{Ni}_{2}$ as $\mathrm{Ni}(\mathrm{II})$ sources cf. ref 51). For comparative purposes of their catalytic properties (vide infra), the mononuclear complex 17 and the known compounds $\mathbf{1 5}^{\mathbf{7 b}}$ and $16^{5 \mathrm{~g}}$ were prepared by analogous procedures.

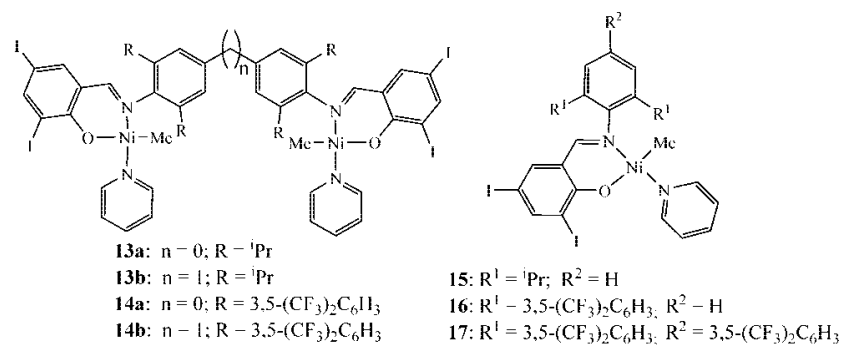

The observation of a single signal for the Ni-Me group in the ${ }^{1} \mathrm{H}$ as well as ${ }^{13} \mathrm{C}$ NMR spectra of the binuclear complexes 13 and $\mathbf{1 4}$ shows that only a single isomer is present. By analogy to similar compounds, for which X-ray crystal structure analyses were obtained, the trans arrangement of the Ni-Me group and the coordinating $\mathrm{O}$-atom was concluded. ${ }^{5 \mathrm{~g}, \mathrm{l}, \mathrm{n}, 17}$ The characteristic signal of the imine protons $(H \mathrm{~N}=\mathrm{C})$ is shifted to higher field by comparison to the free ligand in all complexes (Table 1). The pyridine signals are broadened in ${ }^{1} \mathrm{H}$ as well as ${ }^{13} \mathrm{C}$ NMR spectra, which indicates exchange processes to occur. Within experimental error of the signal integration, no excess free pyridine is observed.

In the methylene-bridged complexes $(\mathbf{1 3 b}, \mathbf{1 4 b})$ and the corresponding salicylaldimines $(\mathbf{1 0 b}, \mathbf{1 1 b})$ employed for their synthesis, the shift of the signals of the methylene protons (aryl-

(17) Connor, E. F.; Younkin, T. R.; Henderson, J. I.; Waltman, A. W.; Grubbs, R. H. Chem. Commun. 2003, 2272-2273.
$\mathrm{CH}_{2}$-aryl) is sensitive to the substitution pattern, e.g., to an incomplete condensation of the anilines to the imines. They are a useful indicator for the purity of the compounds.

In the ${ }^{1} \mathrm{H}$ NMR spectra of the isopropyl-substituted complexes, the $-\mathrm{CH}\left(\mathrm{CH}_{3}\right)_{2}$ septet signal is shifted to lower field by comparison to the free ligands (Table 1). In the complexes, the $-\mathrm{CH}\left(\mathrm{CH}_{3}\right)_{2}$ methyl groups give rise to a set of two doublets. This inequivalence indicates that rotation around the $\mathrm{N}$-aryl and the aryl-isopropyl bonds is hindered. For the 2,6-diarylsubstituted complexes, only a single signal (quartet) is observed for $C_{3}\left({ }^{1} J_{\mathrm{FC}}=272 \mathrm{~Hz}\right)$ and $C C_{3}\left({ }^{2} J_{\mathrm{FC}}=38 \mathrm{~Hz}\right)$ of the $3,5-$ $\left(\mathrm{F}_{3} \mathrm{C}\right)_{2} \mathrm{C}_{6} \mathrm{H}_{3}$ groups in the 2,6-positions of the $\mathrm{N}$-aryl rings. This gives no indication of hindered rotation.

Polymerization Studies. The novel binuclear complexes were studied as single-component catalyst precursors for ethylene polymerization (Table 2). Like their mononuclear analogues, highest average activities (in experiments of 30 to $60 \mathrm{~min}$ duration) are observed at reaction temperatures of 50 to $60{ }^{\circ} \mathrm{C}$ (Figure 1). The maximum activities observed are significantly higher for the binuclear complexes $\left(13 \mathrm{a}: 2.7 \times 10^{4} \mathrm{TO} \mathrm{h}^{-1}\right.$ and 13b: $1.7 \times 10^{4} \mathrm{TO} \mathrm{h}^{-1}$ vs 15: $7.5 \times 10^{3} \mathrm{TO} \mathrm{h}^{-1}$ at $50{ }^{\circ} \mathrm{C}$; 14a: $1.2 \times 10^{5} \mathrm{TO} \mathrm{h}^{-1}$ and $\mathbf{1 4 b}: 1.8 \times 10^{5} \mathrm{TO} \mathrm{h}^{-1}$ at $50^{\circ} \mathrm{C}$ vs 16: $6.4 \times 10^{4} \mathrm{TO} \mathrm{h}^{-1}$ at $60{ }^{\circ} \mathrm{C}$; $40 \mathrm{~atm}$ ethylene pressure in all cases) (Figure 2).

The nature of the bridge ( $n=0$ or 1 ) does not have a clear effect on the polymerization activity comparing the ${ }^{i} \mathrm{Pr}$ - and the 3,5- $\left(\mathrm{CF}_{3}\right)_{2} \mathrm{C}_{6} \mathrm{H}_{3}$-substituted complexes (note that activities are discussed in terms of mol monomer converted per mol of $\mathrm{Ni}$ (II) present, not mol of binuclear complex present). The additional electron-withdrawing 3,5-( $\left(\mathrm{CF}_{3}\right)_{2} \mathrm{C}_{6} \mathrm{H}_{3}$ moiety in the mononuclear complex 17 results in only a small increase in catalyst activity by comparison to $\mathbf{1 6}$. Catalyst stability over time was studied for 13a (entries 17 and 18). Over $1 \mathrm{~h}$ polymerization time, no decrease in catalyst activity was observed.

Polymer molecular weights are influenced by the reaction temperature; with increasing polymerization temperature molecular weights decrease, as expected. The molecular weights of the polymers formed at $50{ }^{\circ} \mathrm{C}$ (where polymerization activities are high) with the binuclear complexes are significantly higher than of the polymers formed with the mononuclear analogues. The observation of higher molecular weights and higher polymerization activities at the same time is an indication that the higher activities by comparison to the mononuclear complexes is rather due to an intrinsically higher rate of chain growth, than to a more efficient activation of the catalyst precursors (dissociation of pyridine).

Polymer microstructures were analyzed by high-temperature ${ }^{13}$ C NMR spectroscopy (Figure 3 ). A low degree of branching was observed. For the samples analyzed, 2 to 12 methyl branches per 1000 carbon atoms were found (Table 2). As expected, the degree of branching increases with the polymerization temperature and depends to some extent also on the catalyst precursor. For polymers prepared at polymerization temperatures of 60 or $70^{\circ} \mathrm{C}$ a small portion of ethyl branches ( $\leq 1 / 1000 \mathrm{C}$ atoms) was also observed (entries 23 and 24). No higher branches were detected. Molecular weights correlate with branching, as $\beta$-hydride transfer is a key step for both the formation of branches as well as chain transfer; with increased branching, molecular weights of the polyethylenes decrease. For samples prepared at polymerization temperatures of $\geq 60{ }^{\circ} \mathrm{C}$ this results in decreased melting temperatures of 110 to $120{ }^{\circ} \mathrm{C}$. ${ }^{18}$

For the mononuclear complex 16, it has been found that dissociation of pyridine limits polymerization activities, particularly at lower polymerization temperatures. ${ }^{20}$ By comparison 
Table 1. Characteristic NMR Signals of Complexes 13a,b, 14a,b, and 17 and of the Corresponding $\mathrm{Free}^{\mathrm{Salicylaldimines}}\left(\mathrm{CD}_{2} \mathrm{Cl}_{2}, \mathrm{25}^{\circ} \mathrm{C},{ }^{1} \mathrm{H}\right.$ : 600 $\left.\mathrm{MHz},{ }^{13} \mathrm{C}: 151 \mathrm{MHz}\right)$

\begin{tabular}{|c|c|c|c|c|c|c|c|}
\hline \multirow[b]{2}{*}{ compound } & \multicolumn{5}{|c|}{${ }^{1} \mathrm{H} \mathrm{NMR} / \delta[\mathrm{ppm}]$} & \multicolumn{2}{|c|}{${ }^{13} \mathrm{C} \mathrm{NMR} / \delta[\mathrm{ppm}]$} \\
\hline & $\mathrm{Ni}-\mathrm{CH}_{3}$ & $-\mathrm{CHCH}_{3}$ & $-\mathrm{CHCH}_{3}$ & $-H \mathrm{C}=\mathrm{N}-$ & $\mathrm{Ar}_{2} \mathrm{CH}_{2}$ & $\mathrm{Ni}-\mathrm{CH}_{3}$ & $-\mathrm{CF}_{3}{ }^{b}$ \\
\hline complex 13a ${ }^{a}$ & -0.57 & 4.13 & 1.061 .57 & 7.26 & & -6.2 & \\
\hline ligand 10a & & 3.08 & 1.32 & 8.26 & & & \\
\hline ligand 10b & & 2.98 & 1.21 & 8.18 & 4.04 & & \\
\hline complex 14a & -0.91 & & & 7.50 & & -7.7 & 123.8 \\
\hline ligand 11a & & & & 7.90 & & & 123.24 \\
\hline complex 17 & -0.91 & & & 7.55 & & -7.7 & $123.50,123.45$ \\
\hline ligand 12 & & & & 7.92 & & & $123.31,123.51$ \\
\hline
\end{tabular}

${ }^{a} \mathrm{C}_{6} \mathrm{D}_{6}, 25{ }^{\circ} \mathrm{C} .{ }^{b}$ Intensity ratio $1: 2$ for $\mathbf{1 2}$ and $\mathbf{1 7}$.

Table 2. Polymerization Results ${ }^{d}$

\begin{tabular}{|c|c|c|c|c|c|c|c|c|c|c|c|}
\hline \multirow[b]{2}{*}{ run } & \multicolumn{4}{|c|}{ polymerization conditions } & \multicolumn{7}{|c|}{ results } \\
\hline & cat. precursor & $n$ (cat.) $[\mu \mathrm{mol}](\mathrm{Ni})$ & $T\left[{ }^{\circ} \mathrm{C}\right]$ & $t[\mathrm{~min}]$ & yield $[\mathrm{g}]$ & $T_{\mathrm{m}}\left[{ }^{\circ} \mathrm{C}\right]$ & crystallinity & $M_{\mathrm{n}}\left[10^{3} \mathrm{~g} \mathrm{~mol}^{-1}\right]$ & $M_{\mathrm{w}} / M_{\mathrm{n}}$ & $\operatorname{TOF}\left[10^{3} \mathrm{~h}^{-1}\right]$ & branches $/ 1000 \mathrm{C}$ \\
\hline 1 & 16 & 8 & 30 & 60 & 7.0 & 131 & $43 \%$ & 154 & 2.0 & 32 & $4^{b}$ \\
\hline 2 & 16 & 15 & 50 & 60 & 20 & 121 & $51 \%$ & 23 & 2.7 & 48 & $9^{b}$ \\
\hline 4 & 16 & 15 & 70 & 60 & 24 & 116 & $46 \%$ & 10 & 2.1 & 55 & n.d. \\
\hline 5 & 16-tmeda & 10 & 20 & 15 & 10 & 133 & $47 \%$ & 401 & 2.9 & 141 & n.d. \\
\hline 6 & 16-tmeda & 10 & 30 & 15 & 3.7 & 126 & $51 \%$ & 69 & 2.4 & 52 & n.d. \\
\hline 9 & $14 a$ & 10 & 50 & 30 & 17 & 127 & $53 \%$ & 74 & 3.2 & 124 & $4^{b}$ \\
\hline 10 & $14 a$ & 15 & 60 & 60 & 21 & 122 & $52 \%$ & 13 & 2.5 & 49 & n.d. \\
\hline 11 & $14 a$ & 5 & 70 & 38 & 3.6 & 118 & $51 \%$ & 15 & 2.1 & 42 & n.d. \\
\hline 12 & 14a-tmeda & 9 & 30 & 15 & 22 & 131 & $52 \%$ & 280 & 3.3 & 341 & $4^{b}$ \\
\hline 13 & $14 \mathrm{~b}$ & 10 & 30 & 60 & 9.4 & 135 & $51 \%$ & 272 & 2.0 & 34 & $2^{b}$ \\
\hline 14 & $14 b$ & 10 & 50 & 25 & 21 & 128 & $54 \%$ & 83 & 3.0 & 184 & $4^{b}$ \\
\hline 15 & $14 b$ & 10 & $50-90^{a}$ & 30 & 31 & 130 & $54 \%$ & 49 & 2.8 & 220 & n.d. \\
\hline 21 & 17 & 14 & 30 & 60 & 16 & 131 & $49 \%$ & 377 & 2.0 & 40 & $2^{b}$ \\
\hline 22 & 17 & 15 & 50 & 60 & 22 & 123 & $51 \%$ & 28 & 2.9 & 54 & $6^{b}$ \\
\hline 23 & 17 & 15 & 60 & 60 & 29 & 119 & $52 \%$ & 17 & 1.9 & 71 & $12^{c}$ \\
\hline 24 & 17 & 14 & 70 & 60 & 23 & 117 & $53 \%$ & 10 & 2.1 & 60 & $12^{c}$ \\
\hline
\end{tabular}

${ }^{a}$ Highly exothermic; ${ }^{b}$ Methyl branches exclusively; ${ }^{c}$ ca. $1 / 1000 \mathrm{C}$ ethyl branches; n.d.: not determined. ${ }^{d}$ Reaction conditions: $p($ ethylene $)=40$ bar; reaction medium $200 \mathrm{~mL}$ of toluene; TOF in $10^{3} \mathrm{~mol}($ ethylene $) \cdot \operatorname{mol}(\mathrm{Ni})^{-1} \cdot \mathrm{h}^{-1}$.

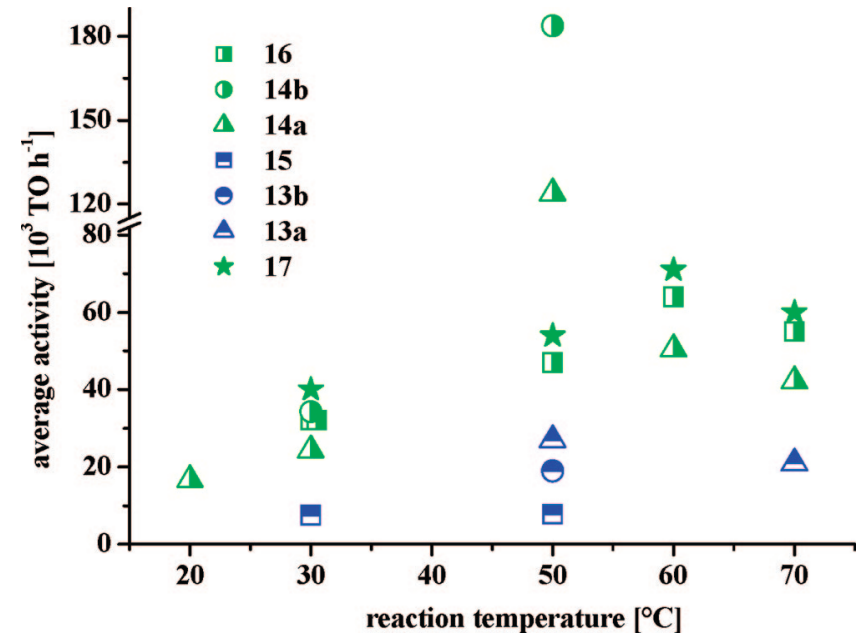

Figure 1. Polymerization activities for different complexes (average activities; 40 atm ethylene pressure).

to pyridine, the tertiary amine $N, N, N^{\prime}, N^{\prime}$-tetramethylethylene diamine (tmeda) binds much weaker. ${ }^{21}$ The tmeda complex 14atmeda was prepared by reacting [(tmeda) $\left.\mathrm{NiMe}_{2}\right]$ with salicyl-

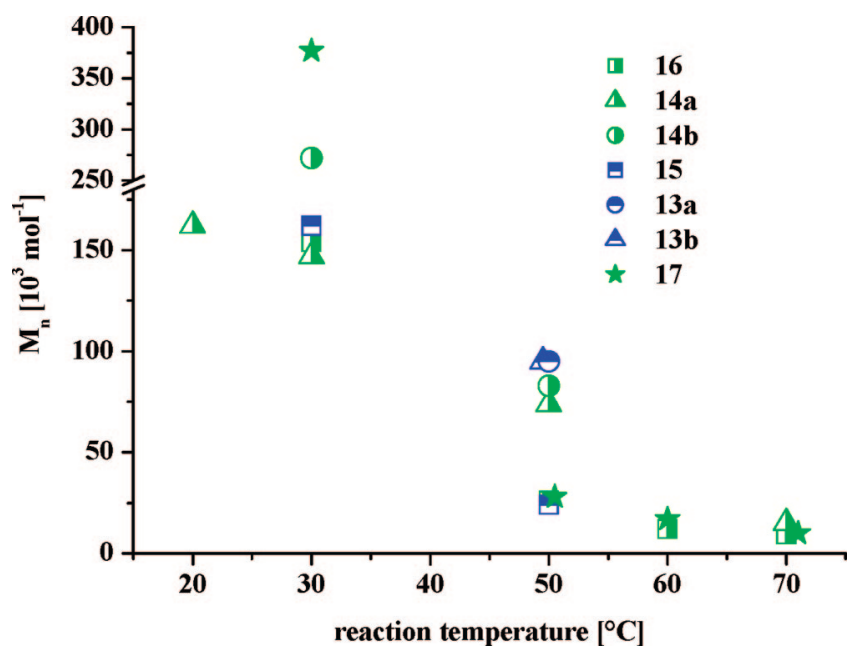

Figure 2. Polymer molecular weight $\left(M_{\mathrm{n}}\right)$ vs polymerization temperature for different complexes.

aldimine 11a without any added pyridine and isolated by removal of solvent. The compound was utilized without further spectroscopic analysis. For comparison, polymerization with the 


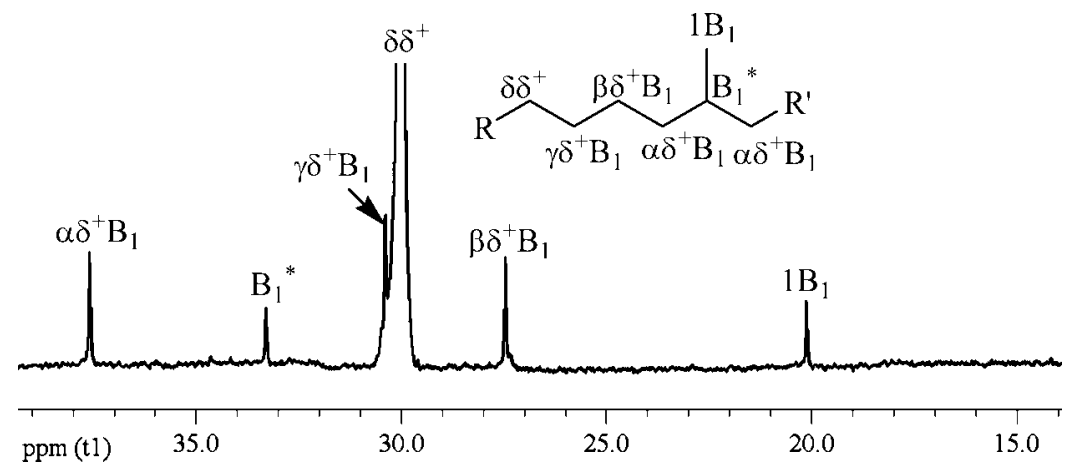

Figure 3. ${ }^{13} \mathrm{C}$ NMR spectrum of slightly branched high molecular weight polyethylene prepared (tetrachloroethane- $d_{2} ; 130{ }^{\circ} \mathrm{C}$ ). Assignments according to ref 19.
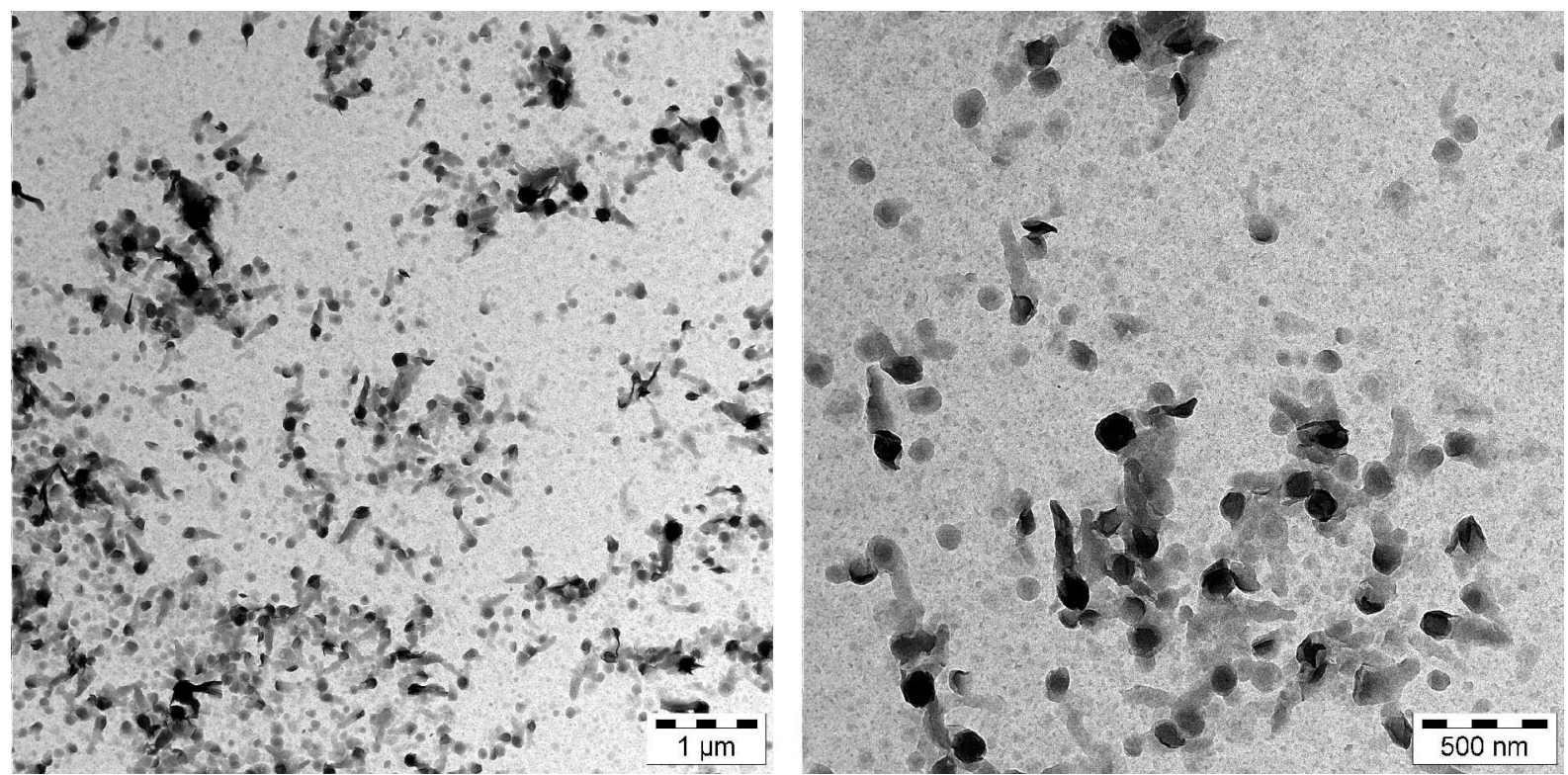

Figure 4. TEM image of polyethylene particles (prepared with 14b, entry 29 in Table 3).

mononuclear 16-tmeda ${ }^{21}$ was studied. Both complexes are highly active at polymerization temperatures of 20 to $30{ }^{\circ} \mathrm{C}$. At the catalyst loadings studied (Table 2), limitation of the reaction time to $15 \mathrm{~min}$ was required to prevent the polymer formed from blocking the stirrer, which resulted in exotherms of up to $100{ }^{\circ} \mathrm{C}$. At $30{ }^{\circ} \mathrm{C}, \mathbf{1 4 a}$-tmeda polymerized ethylene with an average activity of $3.4 \times 10^{5} \mathrm{TO} \mathrm{h}^{-1}$ (entry 12). This is more than an order of magnitude higher than the activity observed with the pyridine analogue 14a at this temperature. At the same time, high molecular weight polymer with $M_{\mathrm{w}} 9.1$ $\times 10^{5} \mathrm{~g} \mathrm{~mol}^{-1}$ and $M_{\mathrm{n}} 2.8 \times 10^{5} \mathrm{~g} \mathrm{~mol}^{-1}$ is obtained.

Polymerization in Aqueous Emulsions. To prepare a polymer dispersion, a high degree of dispersion of the catalyst precursor in the initial reaction mixture is required. For a lipophilic catalyst precursor, this can be achieved by a mini-

(18) (a) Flory, P. J. Trans. Faraday Soc. 1955, 51, 848-857. (b) Sanchez, I. C.; Eby, R. K. J. Res. Nat. Stand. 1973, 77A, 353-358. (c) Alamo, R. G.; Mandelkern, L.; Stack, G. M.; Krönke, C.; Wegner, G. Macromolecules 1994, 27, 147-156. (d) Alamo, R. G.; Mandelkern, L. Macromolecules 1989, 22, 1273-1277. (e) Mathot, V. B. F., Ed. Calorimetry and Thermal Analysis of Polymers; Hanser: Munich, 1994; pp 231-298.

(19) Randall, J. C. J. Macromol. Sci., Rev. Macromol. Chem. Phys. 1989, C29, 201-317.

(20) Wehrmann, P. Dissertation; University of Konstanz, 2007.

(21) Bastero, A.; Kolb, L.; Wehrmann, P.; Bauers, F. M.; Göttker, I.; Monteil, V.; Thomann, R.; Chowdhry, M. M.; Mecking, S. Polym. Mat. Sci. Eng. 2004, 90, 740-1. emulsion technique. ${ }^{7 \mathrm{c}, 8 \mathrm{~b}, 22}$ Pyridine complexes were dissolved in a small amount of toluene and hexadecane as a hydrophobe. The solution was miniemulsified in an aqueous SDS solution by means of high shear generated by ultrasonication. Exposure to ethylene in a pressure reactor afforded polyethylene dispersions (Table 3 ). The binuclear complexes polymerized ethylene in aqueous emulsion with up to $6 \times 10^{3} \mathrm{TO} \mathrm{h}^{-1}$. As observed previously for catalytic polymerizations in aqueous emulsions with various $\kappa^{2}-N, O$-coordinated $\mathrm{Ni}(\mathrm{II})$ catalysts, ${ }^{5 \mathrm{~m}, 7 \mathrm{c}, \mathrm{g}}$ productivities are much decreased by comparison to polymerization in organic solvents. Polymer molecular weights and melting points are similar to those obtained in nonaqueous polymerizations under otherwise identical conditions, overall. Polymerization activity is sustained for hours (entries 28 and 29). This is also confirmed by following the ethylene uptake with mass flow meters (Supporting Information). A tentative explanation for the lower activities observed in the aqueous systems vs polymerization in toluene (Table 2) is a deactivation of the catalyst precursor during miniemulsion preparation and in the very early stages of the polymerization.

TEM images of the dispersions show a rather broad distribution of particle size, in agreement with the DLS traces (Figure 4). A substantial portion of the particles appears to have an

(22) Mecking, S.; Monteil, V.; Huber, J.; Kolb, L.; Wehrmann, P. Makromol. Symp. 2006, 236, 117-123. 
Table 3. Polymerization Results in Aqueous Emulsions ${ }^{d}$

\begin{tabular}{|c|c|c|c|c|c|c|c|c|c|c|c|c|}
\hline \multirow[b]{2}{*}{ run } & \multicolumn{4}{|c|}{ polymerization conditions } & \multicolumn{8}{|c|}{ results } \\
\hline & $\begin{array}{c}\text { cat. } \\
\text { precursor }\end{array}$ & $\begin{array}{c}n(\text { cat. }) \\
{[\mu \mathrm{mol}](\mathrm{Ni})}\end{array}$ & $\begin{array}{c}T \\
{\left[{ }^{\circ} \mathrm{C}\right]} \\
\end{array}$ & $\begin{array}{c}t \\
{[\mathrm{~min}]}\end{array}$ & $\begin{array}{l}\text { polymer } \\
\text { yield }[\mathrm{g}]\end{array}$ & $T_{\mathrm{m}}{ }^{c}\left[{ }^{\circ} \mathrm{C}\right]$ & crystallinity $^{c}$ & $\begin{array}{c}M_{\mathrm{n}} \\
{\left[10^{3} \mathrm{~g} \mathrm{~mol}^{-1}\right]}\end{array}$ & $M_{\mathrm{w}} / M_{\mathrm{n}}$ & TOF & $\begin{array}{c}\text { polymer } \\
\text { solids content }\end{array}$ & $\begin{array}{c}\text { particle } \\
\operatorname{size}^{b}\end{array}$ \\
\hline $2^{a}$ & 16 & 15 & 50 & 60 & 20 & 121 & $51 \%$ & 23 & 2.7 & 48000 & & \\
\hline 25 & 16 & 24 & 50 & 60 & 3.9 & 119 & $47 \%$ & 24 & 2.0 & 5800 & 2.0 & $146 \mathrm{~nm}$ \\
\hline $9^{a}$ & $14 a$ & 10 & 50 & 30 & 17 & 127 & $53 \%$ & 74 & 3.2 & 124000 & & \\
\hline 26 & $14 a$ & 23 & 50 & 60 & 3.8 & 122 & $54 \%$ & 23 & 2.4 & 5900 & 1.9 & $125 \mathrm{~nm}$ \\
\hline 27 & $14 a$ & 26 & 60 & 60 & 2.9 & 116 & $49 \%$ & 15 & 2.2 & 4000 & 1.5 & n.d. \\
\hline $14^{a}$ & $14 b$ & 10 & 50 & 25 & 21 & 128 & $54 \%$ & 83 & 3.0 & 184000 & & \\
\hline 28 & $14 b$ & 23 & 50 & 60 & 4.0 & 123 & $53 \%$ & 27 & 2.5 & 6200 & 2.0 & $136 \mathrm{~nm}$ \\
\hline 29 & $14 b$ & 24 & 50 & 180 & 8 & 123 & $52 \%$ & 32 & 2.9 & 4000 & 4.0 & $235 \mathrm{~nm}$ \\
\hline 30 & 14a-tmeda & 23 & 25 & 60 & 1.6 & 134 & $50 \%$ & 232 & 2.7 & 2500 & 0.8 & $60 \mathrm{~nm}$ \\
\hline 31 & 14a-tmeda & 29 & 25 & 105 & 2.4 & 135 & $50 \%$ & 212 & 3.1 & 1700 & 1.2 & $70 \mathrm{~nm}$ \\
\hline 32 & 15 & 33 & 50 & 60 & 1.2 & 120 & $51 \%$ & 22 & 3.4 & 1300 & 0.6 & $48 \mathrm{~nm}$ \\
\hline 33 & $13 \mathbf{a}$ & 33 & 50 & 60 & 1.5 & 120 & $49 \%$ & 24 & 2.1 & 1600 & 0.75 & n.d. \\
\hline
\end{tabular}

${ }^{a}$ From Table 2 for comparison. Reaction medium: $200 \mathrm{~mL}$ of toluene. ${ }^{b}$ Volume average from DLS. ${ }^{c}$ From DSC of isolated bulk polymer; n.d.: not determined. ${ }^{d}$ Reaction conditions: $p$ (ethylene): 40 bar; reaction medium: $200 \mathrm{~mL}$ of water, $1.5 \mathrm{~g}$ of SDS, $1 \mathrm{~mL}$ of toluene, $1 \mathrm{~mL}$ of hexadecane; TOF in $\operatorname{mol}($ ethylene $) \cdot \operatorname{mol}(\mathrm{Ni})^{-1} \cdot h^{-1}$.

approximately circular circumference, but irregular structures are also observed.

\section{Summary and Conclusions}

Four novel binuclear $\mathrm{Ni}$ (II) methylpyridine complexes of di(salicylaldimines) bridged in the $p$-position of the $\mathrm{N}$-aryl moiety were prepared and characterized, and their polymerization properties toward ethylene studied. The pyridine complexes are active over the entire temperature range studied, 20 to 70 ${ }^{\circ} \mathrm{C}$, as single-component catalyst precursors, without the necessity of an activator. Maximum productivities were observed at $50{ }^{\circ} \mathrm{C}$ in the experiments performed; at higher temperatures some deactivation occurs. In addition to the pyridine complexes, a complex of the less strongly coordinating tertiary amine tmeda was studied. A high activity was observed at a low polymerization temperature of $20{ }^{\circ} \mathrm{C}$. As with the mononuclear complexes, substitution in the $2,2^{\prime}, 6,6^{\prime}$-position of the $\mathrm{N}$-aryl moieties with 3,5-bis(trifluoromethyl)phenyl groups results in more active catalysts than isopropyl substitution.

Polymerization activities of all binuclear complexes are substantially higher than those of mononuclear analogues, that is, compounds with either $\mathrm{R}=\mathrm{H}$ or $\mathrm{R}=3,5-\left(\mathrm{F}_{3} \mathrm{C}\right)_{2} \mathrm{C}_{6} \mathrm{H}_{3}$ instead of the bridging moiety. A maximum activity of $3.4 \times 10^{5} \mathrm{TO}$ $\mathrm{h}^{-1}$ was observed, with formation of high molecular weight polymer of $M_{\mathrm{w}} 9.2 \times 10^{5} \mathrm{~g} \mathrm{~mol}^{-1}$ and $M_{\mathrm{n}} 2.8 \times 10^{5} \mathrm{~g} \mathrm{~mol}^{-1}$. At the same time, the catalyst precursors are conveniently accessible. The higher polymerization activity of the binuclear complexes by comparison to the mononuclear analogues appears to be due rather to an intrinsically higher rate of chain growth, than to a more efficient activation of the catalyst precursors (dissociation of pyridine). The origin of the higher chain growth rates, which corresponds to a difference in activation energy of only ca. $1 \mathrm{kcal}$, remains unclear. The observation of high polymerization activities $\left(\geq 10^{5} \mathrm{TO} \mathrm{h}^{-1}\right)$ and formation of high molecular weight polymer $\left(M_{\mathrm{n}} \geq 10^{5} \mathrm{~g} \mathrm{~mol}^{-1}\right)$ at the same time has not been reported for binuclear neutral $\mathrm{Ni}(\mathrm{II})$ polymerization catalysts. Polymer microstructure is affected by chain walking only to a small extent. Linear polyethylenes with, for example, two methyl branches per 1000 carbon atoms (polymerization temperature $30{ }^{\circ} \mathrm{C}$ ) are obtained.

Polymerizations can be carried out in aqueous emulsions, to afford dispersions of high molecular weight linear polyethylene. Productivities are substantially lower than in polymerizations in nonaqueous systems, however, as observed previously for mononuclear salicylaldiminato-substituted neutral Ni(II) polymerization catalysts.

\section{Experimental Section}

Materials and General Considerations. Unless noted otherwise, all manipulations of nickel complexes were carried out under an inert atmosphere using standard glovebox or Schlenk techniques. Toluene and pentane were distilled from sodium and diethyl ether from sodium/benzophenone under argon. Hexadecane was degassed under argon. Demineralized water was distilled under nitrogen and degassed three times after distillation. Pyridine was distilled from $\mathrm{CaH}_{2}$. 4,4'-Diaminodiphenyl methane (>98\%), 4,4'-diamino$2,2^{\prime}, 6,6^{\prime}$-tetraisopropyldiphenylmethane (techn. $>80 \%, \mathbf{7 b}$ ), and benzidine ( $>98 \%$ ) supplied by Fluka, 3,5-bis(trifluoromethyl)phenyl bromide supplied by ABCR, 2,4,6-tribromoaniline (98\%) supplied by Lancaster, 2,6-diisopropylaniline (92\%) and tetra- $n$-butylammonium tribromide ( $>98 \%$ ) supplied by Acros, and 3,5-diiodosalicylaldehyde (97\%) supplied by Aldrich were used as received. [(tmeda) $\mathrm{NiMe}_{2}$ ] was supplied by MCAT (Konstanz, Germany). [(pyridine) $\mathrm{NiMe}_{2}$ ] was obtained by modification of a literature procedure. ${ }^{23}$ Complexes $15^{7 \mathrm{~b}}$ and $16^{5 \mathrm{~g}}$ were prepared according to published procedures.

NMR spectra were recorded on a Varian Unity INOVA 400 or on a Bruker AC 250 spectrometer. ${ }^{1} \mathrm{H}$ and ${ }^{13} \mathrm{C}$ NMR chemical shifts were referred to the solvent signal. High-temperature NMR measurements of polyethylenes were performed in 1,1,2,2-tetrachloroethane- $d_{2}$ at $130{ }^{\circ} \mathrm{C}$. The branching structure was assigned according to refs 19 and 24. Differential scanning calorimetry (DSC) was performed on a Netzsch Phoenix 204 F1 at a heating rate of $10 \mathrm{~K} \mathrm{~min}^{-1}$. DSC data reported are from second heating cycles. Polymer crystallinities were calculated based on a melt enthalpy of $293 \mathrm{~J} \mathrm{~g}^{-1}$ for $100 \%$ crystalline polyethylene. Gel permeation chromatography (GPC) was carried out in 1,2,4-trichlorobenzene at $160{ }^{\circ} \mathrm{C}$ on a Polymer Laboratories 220 instrument equipped with Olexis columns with differential refractive index, viscosity, and light scattering $\left(15^{\circ}\right.$ and $\left.90^{\circ}\right)$ detectors. Data reported were determined via universal calibration (for samples with $M_{\mathrm{n}}<10^{5} \mathrm{~g}$ $\left.\mathrm{mol}^{-1}\right)$ and triple detection $\left(M_{\mathrm{n}}>10^{5} \mathrm{~g} \mathrm{~mol}^{-1}\right)$. Both methods were in good agreement with one another. Dynamic light scattering was carried out on a Malvern Nano Zeta Sizer. For the determination of particle size, a few drops of a latex sample were diluted with ca. $3 \mathrm{~mL}$ of water. TEM images were obtained on a Zeiss Libra 120 instrument. Dispersions were dialyzed for TEM analysis to remove any free surfactant and applied to a copper grid. The acceleration voltage was $120 \mathrm{keV}$, and the samples were not contrasted. Elemental analyses were performed up to $950{ }^{\circ} \mathrm{C}$ on

(23) Cámpora, J.; Conejo, M. d. M.; Mereiter, K.; Palma, P.; Pérez, C.; Reyes, M. L.; Ruiz, C. J. Organomet. Chem. 2003, 683, 220-239.

(24) Axelson, D. E.; Levy, G. C.; Mandelkern, L. Macromolecules 1979, $12,41-52$. 
an Elementar Vario EL. Mass spectrometry with ESI was carried out on a Bruker Esquire 3000 plus instrument in positive mode. Samples were applied as methanol solutions. EI-MS was performed on a Finnegan MAT instrument at 20 to $400{ }^{\circ} \mathrm{C}$ and 30 to $70 \mathrm{eV}$ electron energy (note that for higher molecular weights, $>$ ca. $700 \mathrm{~g}$ $\mathrm{mol}^{-1}, M$ were underestimated by ca. $1 \mathrm{~g} \mathrm{~mol}^{-1}$ ).

Synthesis of Anilines and Salicylaldimines. 4-Bromo-2,6diisopropylaniline. To tetra- $n$-butylammonium tribromide $(34.3 \mathrm{~g}$, $71 \mathrm{mmol})$, calcium carbonate $(30 \mathrm{~g})$, and $50 \mathrm{~mL}$ of methanol, a solution of 2,6-diisopropylaniline $(12.6 \mathrm{~g}, 71 \mathrm{mmol})$ in $30 \mathrm{~mL}$ of methanol was added and the mixture was stirred overnight. During this time, the color changed from bright yellow to slightly greenish. The solvent was removed in vacuo, and the residue was suspended in toluene. Washing with aqueous EDTA solution resulted in complete dissolution of the solid. The aqueous phase was separated and extracted twice with toluene. The combined organic phases were dried over magnesium sulfate, and the solvent was removed in vacuo. $17.7 \mathrm{~g}$ (69 mmol, 97\%) of 2,6-diisopropyl-4-bromoaniline was obtained as an orange-red oil. ${ }^{1} \mathrm{H}$ NMR (400 $\left.\mathrm{MHz}, \mathrm{CDCl}_{3}\right)$ : $\delta /$ ppm $7.13(2 \mathrm{H}, \mathrm{Ar}-\mathrm{H}), 3.86(2 \mathrm{H}, \mathrm{NH}), 2.84\left(\mathrm{sep},{ }^{3} J_{\mathrm{HH}}=6.8\right.$ $\left.\mathrm{Hz}, 2 \mathrm{H}, \mathrm{CH}-\mathrm{CH}_{3}\right), 1.22\left(\mathrm{~d}, \mathrm{~J}=6.8 \mathrm{~Hz}, 12 \mathrm{H}, \mathrm{CH}_{3}\right) .{ }^{13} \mathrm{C} \mathrm{NMR}$ $\left(101 \mathrm{MHz}, \mathrm{CDCl}_{3}\right): \delta / \mathrm{ppm} 139.08,133.99,125.15,110.37$ (C-Aryl), $27.51\left(\mathrm{CH}-\mathrm{CH}_{3}\right), 21.79\left(\mathrm{CH}_{3}\right)$

$\mathbf{2 , 2}, \mathbf{6}, \mathbf{6}^{\prime}$-Tetraisopropylbenzidine (7a). ${ }^{\mathbf{1 6}}$ Sodium formiate (125 mmol, prepared from sodium hydroxide and formic acid), dodecyltrimethyl ammonium bromide $(1.0 \mathrm{~g})$, palladium on charcoal (0.46 g; 3 wt \% Pd), sodium hydroxide (1.8 g), 2,6-diisopropyl4-bromoaniline (7.7 g, $30 \mathrm{mmol}$ ), and $50 \mathrm{~mL}$ of water were refluxed with vigorous stirring, with a slow stream of air through the reaction mixture. After $10 \mathrm{~h}$, another batch of sodium formiate (125 mmol) was added, and refluxing was continued for $20 \mathrm{~h}$. After cooling to room temperature, to the biphasic mixture was added $100 \mathrm{~mL}$ of diethyl ether. The aqueous phase was extracted twice with diethyl ether. The combined organic phases were dried over magnesium sulfate. After concentration in vacuo, a red oil was obtained, from which the product crystallized slowly in the form of pale violet crystals. The product was recrystallized from pentane, to afford $1.8 \mathrm{~g}$ (5.1 mmol; $34 \%$ yield) of $\mathbf{7 a}$.

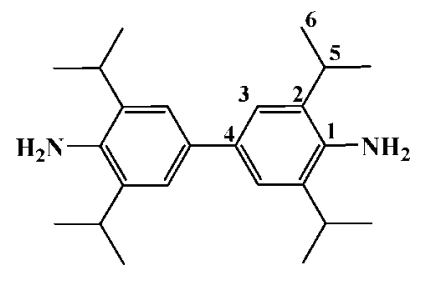

${ }^{1} \mathrm{H}$ NMR (400 MHz, $\mathrm{CD}_{2} \mathrm{Cl}_{2}$ ): $\delta / \mathrm{ppm} 7.31$ (4 H, 3-H), 3.88 (4 $\mathrm{H}, \mathrm{N}-\mathrm{H}), 3.11\left(\mathrm{sep},{ }^{2} J_{\mathrm{HH}}=6.7 \mathrm{~Hz}, 4 \mathrm{H}, 5-\mathrm{H}\right), 1.45\left(\mathrm{~d},{ }^{3} J_{\mathrm{HH}}=6.7\right.$ $\mathrm{Hz}, 24 \mathrm{H}, 6-\mathrm{H}) .{ }^{13} \mathrm{C}$ NMR (151 MHz, $\left.\mathrm{CD}_{2} \mathrm{Cl}_{2}\right): \delta / \mathrm{ppm} 139.21\left(\mathrm{C}^{1}\right)$, $132.83\left(\mathrm{C}^{2}\right), 132.74\left(\mathrm{C}^{4}\right), 121.36\left(\mathrm{C}^{3}\right), 28.16\left(\mathrm{C}^{5}\right), 22.44\left(\mathrm{C}^{6}\right)$. EIMS m/z $352.6\left(\mathrm{M}^{+}\right)$. Anal. Calcd for $\mathrm{C}_{24} \mathrm{H}_{36} \mathrm{~N}_{2}(M=352.56 \mathrm{~g}$ $\mathrm{mol}^{-1}$ ): C 81.76, H 10.29, N 7.95. Found: C 81.05, H 9.65, N 7.42 .

3,3',5,5' -Tetrabromo-4,4'-diaminodiphenylmethane. To a suspension of tetra- $n$-butylammonium tribromide $(9.6 \mathrm{~g}, 20 \mathrm{mmol})$ and calcium carbonate $(2.2 \mathrm{~g}, 22 \mathrm{mmol})$ in $50 \mathrm{~mL}$ of methanol was added a solution of 4,4'-diaminodiphenylmethane $(1 \mathrm{~g}, 5 \mathrm{mmol})$ in $30 \mathrm{~mL}$ of methanol, and the mixture was stirred at room temperature. The color changed from an initial orange to light green. After $12 \mathrm{~h}$, the solvent was removed in vacuo, and the residue was extracted with hot toluene on a frit. The extract was concentrated to dryness and washed twice each with water and methanol. The resulting crude product was recrystallized from toluene and washed with methanol to afford $2.1 \mathrm{~g}(4.1 \mathrm{mmol}, 82 \%)$ of $3,3^{\prime}, 5,5^{\prime}-$ tetrabromo-4, $4^{\prime}$-diaminodiphenylmethane as brown needles.<smiles>Nc1c(Br)cc(Cc2cc(Br)c(N)c(Br)c2)cc1Br</smiles>

${ }^{1} \mathrm{H}$ NMR (400 MHz, $\left.\mathrm{C}_{6} \mathrm{D}_{6}\right)$ : $\delta / p p m 6.89(4 \mathrm{H}, 3-\mathrm{H}), 3.91(4 \mathrm{H}$, $\left.\mathrm{NH}_{2}\right), 3.01(2 \mathrm{H}, 5-\mathrm{H})$. Anal. Calcd for $\mathrm{C}_{13} \mathrm{H}_{10} \mathrm{Br}_{4} \mathrm{~N}_{2}(M=513.85$ $\mathrm{g} \mathrm{mol}^{-1}$ ): C 30.39, H 1.96, N 5.45. Found: C 28.71, H 1.71, N 5.48 .

General Procedure for Suzuki Coupling. Aryl bromide, 3,5bis(trifluoromethyl)phenylboronic acid (1.1 equiv), and sodium carbonate ( 2 equiv) were placed in a Schlenk tube. The tube was evacuated and back-filled with argon. Via septum, water $(5 \mathrm{~mL})$, ethanol $(10 \mathrm{~mL})$, and toluene $(30 \mathrm{~mL})$ were added. An orange solution of bis(dibenzylidene acetone)palladium(II) (0.5 mol \%) and triphenylphosphine $(1 \mathrm{~mol} \%)$ in $5 \mathrm{~mL}$ of toluene was added, and the mixture was stirred for $12 \mathrm{~h}$ at $90{ }^{\circ} \mathrm{C}$. Further workup was carried out as outlined for the individual compounds.

3,3',5,5'-Tetrakis(3,5-bis(trifluormethyl)phenyl)-4,4'-diaminodiphenylmethane $(\mathbf{8 b})$. A $1.0 \mathrm{~g}(2.0 \mathrm{mmol})$ amount of $3,3^{\prime}, 5,5^{\prime}-$ tetrabromo-4,4'-diaminodiphenylmethane was reacted as outlined above. The biphasic mixture was filtered through a paper filter, and the phases were separated. The aqueous phase was extracted twice with diethyl ether. The combined organic phases were dried over $\mathrm{MgSO}_{4}$, and the solvent was removed in vacuo. The residue was recrystallized from pentane to afford $1.9 \mathrm{~g}(1.9 \mathrm{mmol} ; 95 \%$ yield) of $\mathbf{8 b}$ as a pale yellow powder.<smiles>Nc1c(-c2cc(C(F)(F)F)cc(C(F)(F)F)c2)cc(C#Cc2cc(-c3cc(C(F)(F)F)cc(C(F)(F)F)c3)c(N)c(-c3cc(C(F)(F)F)cc(C(F)(F)F)c3)c2)cc1-c1cc(C(F)(F)F)cc(C(F)(F)F)c1</smiles>

${ }^{1} \mathrm{H}$ NMR (600 MHz, $\mathrm{CD}_{2} \mathrm{Cl}_{2}$ ): $\delta / p p m 8.06(8 \mathrm{H}, 6-\mathrm{H}), 7.98$ (4 $\mathrm{H}, 8-\mathrm{H}), 7.13$ (4 H, 3-H), $4.01(4 \mathrm{H}, 10-\mathrm{H}), 3.73(4 \mathrm{H}, \mathrm{NH}) .{ }^{13} \mathrm{C}$ NMR (151 MHz, $\left.\mathrm{CD}_{2} \mathrm{Cl}_{2}\right)$ : $\delta / \mathrm{ppm} 141.57\left(\mathrm{C}^{5}\right), 139.11\left(\mathrm{C}^{1}\right), 132.23$ $\left(\mathrm{q},{ }^{2} J_{\mathrm{CF}}=32.9 \mathrm{~Hz}, \mathrm{C}^{7}\right), 132.09\left(\mathrm{C}^{4}\right), 131.33\left(\mathrm{C}^{3}\right), 129.81\left(\mathrm{C}^{6}\right)$, $125.83\left(\mathrm{C}^{2}\right), 123.47\left(\mathrm{q},{ }^{1} J_{\mathrm{CF}}=272.6 \mathrm{~Hz}, \mathrm{C}^{9}\right), 121.54\left(\mathrm{C}^{8}\right), 39.83$ $\left(\mathrm{C}^{10}\right)$. EI-MS: $m / z$ 1046.2 $\left(\mathrm{M}^{+}\right)$. Anal. Calcd for $\mathrm{C}_{45} \mathrm{H}_{22} \mathrm{~F}_{24} \mathrm{~N}_{2}(M$ $\left.=1046.63 \mathrm{~g} \mathrm{~mol}^{-1}\right)$ : C 51.64, H 2.12, N 2.68. Found: C 51.44, H 2.43, N 2.67 .

$\mathbf{3 , 3}, \mathbf{5}, \mathbf{5}^{\prime}$-Tetrabromobenzidine. A $29 \mathrm{~g}(60 \mathrm{mmol})$ sample of tetra- $n$-butylammonium tribromide and $6.6 \mathrm{~g}(66 \mathrm{mmol})$ of $\mathrm{CaCO}_{3}$ were suspended in $50 \mathrm{~mL}$ of methanol. A solution of $2.8 \mathrm{~g} \mathrm{(15}$ $\mathrm{mmol}$ ) of benzidine in $30 \mathrm{~mL}$ of methanol was added under stirring. The color changed from pale orange to green, with slight gas evolution. After stirring for $12 \mathrm{~h}$, the reaction mixture was evaporated to dryness. The residue was extracted on a frit with hot toluene. The extract was concentrated and chilled. The crystalline precipitate formed was isolated, recrystallized from toluene, and washed with methanol to afford $4.7 \mathrm{~g}(9.4 \mathrm{mmol}, 63 \%)$ of tetrabromobenzidine as pale brown needles. ${ }^{1} \mathrm{H}$ NMR $(400 \mathrm{MHz}$, $\mathrm{CDCl}_{3}$ ): $\delta / \mathrm{ppm} 7.50$ (4 H, Ar-H), 4.57 (br, $\left.4 \mathrm{H}, \mathrm{NH}\right)$. EI-MS: $\mathrm{m} / \mathrm{z}$, $500.3\left(\mathrm{M}^{+}\right)$. Anal. Calcd for $\mathrm{C}_{12} \mathrm{H}_{8} \mathrm{Br}_{4} \mathrm{~N}_{2}\left(M=499.82 \mathrm{~g} \mathrm{~mol}^{-1}\right)$ : C 28.84, H 1.61, N 5.60. Found: C 28.71, H 1.71, N 5.48.

2,2',6,6'-Tetrakis[3,5-bis(trifluoromethyl)phenyl]benzidine (8a). A $2.3 \mathrm{~g}$ (4.6 mmol) portion of 2,2',6,6'-tetrabromobenzidine were reacted according to the general procedure for Suzuki coupling. The crude product precipitated as a gray solid. It was separated, washed with methanol, dissolved in hot toluene, and filtered over 
diatomaceous earth. The product crystallized from the filtrate upon cooling. Drying in vacuo afforded $3.5 \mathrm{~g}$ (3.4 mmol, 74\%) of $\mathbf{8 a}$ as yellow-white needles.

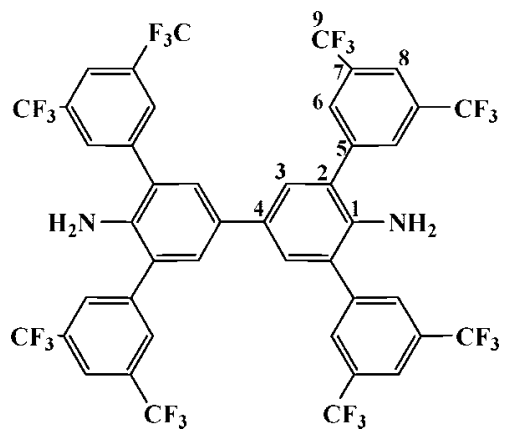

${ }^{1} \mathrm{H}$ NMR (600 MHz, $\left.\mathrm{CD}_{2} \mathrm{Cl}_{2}\right): \delta / p p m 8.11(8 \mathrm{H}, 6-\mathrm{H}), 8.01$ (4 $\mathrm{H}, 8-\mathrm{H}), 7.47$ (4 H, 3-H), 3.83 (4 H, N-H). ${ }^{13} \mathrm{C}$ NMR $(151 \mathrm{MHz}$, $\left.\mathrm{CD}_{2} \mathrm{Cl}_{2}\right): \delta / \mathrm{ppm} 141.39\left(\mathrm{C}^{5}\right), 139.94\left(\mathrm{C}^{1}\right), 132.30\left(\mathrm{q},{ }^{2} J_{\mathrm{CF}}=33.3\right.$ $\left.\mathrm{Hz}, \mathrm{C}^{7}\right), 130.86\left(\mathrm{C}^{4}\right), 129.91\left(\mathrm{C}^{6}\right), 128.79\left(\mathrm{C}^{3}\right), 126.14\left(\mathrm{C}^{2}\right), 123.44$ $\left(\mathrm{q},{ }^{1} J_{\mathrm{CF}}=272.5 \mathrm{~Hz}, \mathrm{C}^{9}\right), 121.76\left(\mathrm{C}^{8}\right)$. EI-MS: $m / z 1032.6\left(\mathrm{M}^{+}\right)$. Anal. Calcd for $\mathrm{C}_{44} \mathrm{H}_{20} \mathrm{~F}_{24} \mathrm{~N}_{2}\left(\mathrm{M}=1032.63 \mathrm{~g} \mathrm{~mol}^{-1}\right)$ : $\mathrm{C} 51.98, \mathrm{H}$ 1.95, N 2.71. Found: C 51.17, H 2.07, N 2.67.

2,4,6-Tris[3,5-bis(trifluoromethyl)phenyl]aniline. A $1.6 \mathrm{~g}$ (4.7 mmol) amount of 2,4,6-tribromoaniline was reacted according to the above general procedure for Suzuki coupling. Workup analogous to $\mathbf{8 b}$ afforded $2.3 \mathrm{~g}(3.2 \mathrm{mmol} ; 68 \%)$ of 2,4,6-tris[3,5-bis(trifluoromethyl)phenyl]aniline.<smiles></smiles>

${ }^{1} \mathrm{H}$ NMR (600 MHz, $\mathrm{CD}_{2} \mathrm{Cl}_{2}$ ): $\delta / \mathrm{ppm} 8.16(4 \mathrm{H}, 6-\mathrm{H}), 8.13$ (2 H, 11-H), 8.07 (2 H, 8-H), 7.91 (1 H, 13-H), 7.58 (2 H, 3-H), 4.02 $(2 \mathrm{H}, \mathrm{NH}) .{ }^{13} \mathrm{C}$ NMR $\left(151 \mathrm{MHz}, \mathrm{CD}_{2} \mathrm{Cl}_{2}\right): \delta / \mathrm{ppm} 142.27\left(\mathrm{C}^{10}\right)$, $141.81\left(\mathrm{C}^{1}\right), 140.95\left(\mathrm{C}^{5}\right), 132.61\left(\mathrm{q},{ }^{2} J_{\mathrm{CF}}=33.4 \mathrm{~Hz}, \mathrm{C}^{7}\right), 132.18$ $\left(\mathrm{q},{ }^{2} J_{\mathrm{CF}}=33.5 \mathrm{~Hz}, \mathrm{C}^{12}\right), 130.00\left(\mathrm{C}^{6}\right), 129.74\left(\mathrm{C}^{3}\right), 128.84\left(\mathrm{C}^{4}\right)$, $126.58\left(\mathrm{C}^{11}\right), 126.31\left(\mathrm{C}^{2}\right), 123.68\left(\mathrm{q},{ }^{1} J_{\mathrm{CF}}=272.8 \mathrm{~Hz}, \mathrm{C}^{14}\right), 123.50$ $\left(\mathrm{q},{ }^{1} J_{\mathrm{CF}}=273.0 \mathrm{~Hz}, \mathrm{C}^{9}\right), 122.14\left(\mathrm{C}^{8}\right), 120.56\left(\mathrm{C}^{13}\right) . \mathrm{EI}-\mathrm{MS} \mathrm{m} / \mathrm{z}=$ $729.5\left(\mathrm{M}^{+}\right)$. Anal. Calcd for $\mathrm{C}_{30} \mathrm{H}_{13} \mathrm{~F}_{18} \mathrm{~N}\left(M=729.4 \mathrm{~g} \mathrm{~mol}^{-1}\right)$ : $\mathrm{C}$ 49.40, H 1.80, N 1.92. Found: C 49.16, H 1.95, N 2.00.

General Procedure for Condensation of Anilines with 3,5Diiodosalicylaldehyde. In a flask equipped with a Dean-Stark condenser, the aniline, 3,5-diiodosalicylaldehyde (1.2 equiv), and a catalytic amount of $p$-toluenesulfonic acid were dissolved in 200 $\mathrm{mL}$ of toluene. The mixture was degassed by several cycles of evacuating and back-filling with inert atmosphere. The mixture was stirred at $80{ }^{\circ} \mathrm{C}$, and the pressure was reduced until the solvent boiled. The mixture was kept at $80^{\circ} \mathrm{C}$ for $7 \mathrm{~h}$, while the solvent collected in the Dean-Stark condenser was removed periodically (to collect a total of ca. $150 \mathrm{~mL}$ ). The reaction mixture was concentrated, and to the brown viscous residue was added $20 \mathrm{~mL}$ of pentane, which initiated crystallization of the product. The crude product was recrystallized from methanol, to afford the aldimine as a yellow solid.

$\left[\left\{\left(2,6-{ }^{i} \mathbf{P r}_{2}-4-\mathrm{yl}-\mathrm{C}_{6} \mathrm{H}_{2}\right)-\mathrm{N}=\mathbf{C}(\mathbf{H})-\left(3,5-\mathrm{I}_{2}-\mathbf{2}-(\mathrm{OH})-\mathrm{C}_{6} \mathrm{H}_{2}\right)\right\}_{2}\right]$ (10a). Yield: $75 \%$. ${ }^{1} \mathrm{H}$ NMR $\left(600 \mathrm{MHz}, \mathrm{CD}_{2} \mathrm{Cl}_{2}\right)$ : $\delta / \mathrm{ppm} 8.26(2 \mathrm{H}, 7-\mathrm{H})$, 8.25 (b, 2 H, 4-H), 7.78 (b, 2 H, 6-H), 7.47 (4 H, 10-H), 3.08 (sept, $\left.{ }^{3} J_{\mathrm{HH}}=6.8 \mathrm{~Hz}, 4,12-\mathrm{H}\right), 1.32\left(\mathrm{~d},{ }^{3} J_{\mathrm{HH}}=6.8 \mathrm{~Hz}, 24 \mathrm{H}, 13-\mathrm{H}\right) .{ }^{13} \mathrm{C}$
NMR (151 MHz, $\left.\mathrm{CD}_{2} \mathrm{Cl}_{2}\right)$ : $\delta / \mathrm{ppm} 165.16\left(\mathrm{C}^{7}\right), 160.46\left(\mathrm{C}^{2}\right), 149.44$ $\left(C^{4}\right), 144.36\left(C^{8}\right), 140.90\left(C^{6}\right), 139.50\left(C^{9}\right), 139.36\left(C^{11}\right), 122.38$ $\left(C^{10}\right), 120.32\left(C^{1}\right), 87.03\left(C^{5}\right), 79.83\left(C^{3}\right), 28.46\left(C^{12}\right), 23.45\left(C^{13}\right)$. Anal. Calcd for $\mathrm{C}_{38} \mathrm{H}_{40} \mathrm{I}_{4} \mathrm{~N}_{2} \mathrm{O}_{2}\left(M=1064.35 \mathrm{~g} \mathrm{~mol}^{-1}\right)$ : C 42.88, H 3.79, N 2.63. Found: C 42.81, H 3.89, N 2.71 .

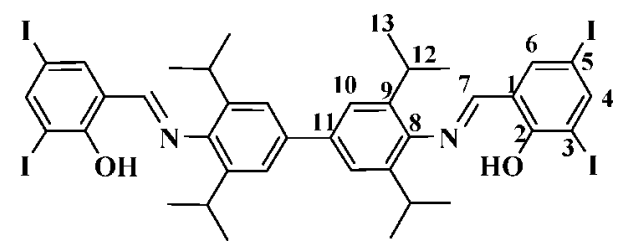

[CH $\mathrm{CH}_{2}\left\{\left(2,6-{ }^{i} \mathrm{Pr}_{2}\right)_{2}-4-\mathrm{yl}-\mathrm{C}_{6} \mathrm{H}_{2}\right)-\mathrm{N}=\mathrm{C}(\mathrm{H})-\left(3,5-\mathrm{I}_{2}-2-(\mathrm{OH})-\right.$ $\left.\left.\left.\mathrm{C}_{6} \mathbf{H}_{2}\right)\right\}_{2}\right]$ (10b). Yield: $41 \%$. ${ }^{1} \mathrm{H}$ NMR $\left(600 \mathrm{MHz}, \mathrm{CD}_{2} \mathrm{Cl}_{2}\right): \delta / \mathrm{ppm}$ $8.22\left(\mathrm{~d},{ }^{4} J_{\mathrm{HH}}=2.0 \mathrm{~Hz}, 2 \mathrm{H}, 4-\mathrm{H}\right), 8.18(2 \mathrm{H}, 7-\mathrm{H}), 7.73\left(\mathrm{~d},{ }^{4} J_{\mathrm{HH}}\right.$ $=2.0 \mathrm{~Hz}, 2 \mathrm{H}, 6-\mathrm{H}), 7.14(4 \mathrm{H}, 10-\mathrm{H}), 4.04(2 \mathrm{H}, 14-\mathrm{H}), 2.98$ $\left(\mathrm{sept},{ }^{3} J_{\mathrm{HH}}=6.8 \mathrm{~Hz}, 4 \mathrm{H}, 12-\mathrm{H}\right), 1.21\left(\mathrm{~d},{ }^{3} J_{\mathrm{HH}}=6.8 \mathrm{~Hz}, 24 \mathrm{H}\right.$, 13-H). ${ }^{13} \mathrm{C}$ NMR (151 MHz, $\left.\mathrm{CD}_{2} \mathrm{Cl}_{2}\right): \delta / \mathrm{ppm} 165.09\left(\mathrm{C}^{7}\right), 160.59$ $\left(C^{2}\right), 149.31\left(C^{4}\right), 143.01\left(C^{8}\right), 140.80\left(C^{6}\right), 139.10\left(C^{9}\right), 138.99$ $\left(\mathrm{C}^{11}\right), 123.82\left(\mathrm{C}^{10}\right), 120.31\left(\mathrm{C}^{1}\right), 87.05\left(\mathrm{C}^{5}\right), 79.64\left(\mathrm{C}^{3}\right), 41.75$ $\left(\mathrm{C}^{14}\right), 28.26\left(\mathrm{C}^{12}\right), 23.44\left(\mathrm{C}^{13}\right)$. ES-MS: $m / z$ 1077.9 $\left(\mathrm{M}^{+}\right)$. Anal. Calcd for $\mathrm{C}_{39} \mathrm{H}_{42} \mathrm{I}_{4} \mathrm{~N}_{2} \mathrm{O}_{2}\left(M=1078.38 \mathrm{~g} \mathrm{~mol}^{-1}\right)$ : C 43.44, H 3.93, N 2.60. Found: C 43.47, H 4.20, N 2.53.<smiles>CC(C)c1cc([Al]c2cc(C(C)C)c(N=Cc3cc(I)cc(I)c3O)c(C(C)C)c2)cc(C(C)C)c1N=Cc1cc(I)cc(I)c1O</smiles>

[\{(2,6-(3,5- $\left.\left.\left(\mathrm{CF}_{3}\right)_{2} \mathrm{C}_{6} \mathrm{H}_{3}\right)_{2}-4-\mathrm{yl}-\mathrm{C}_{6} \mathrm{H}_{2}\right)-\mathrm{N}=\mathrm{C}(\mathrm{H})-\left(3,5-\mathrm{I}_{2}-2-(\mathrm{OH})-\right.$ $\left.\left.\mathbf{C}_{6} \mathbf{H}_{2}\right)\right\}_{2}$ ] (11a). Yield: $79 \%$. ${ }^{1} \mathrm{H}$ NMR $\left(400 \mathrm{MHz}, \mathrm{CD}_{2} \mathrm{Cl}_{2}\right): \delta / \mathrm{ppm}$ $12.94(2 \mathrm{H}, \mathrm{OH}), 8.14\left(\mathrm{~d},{ }^{4} J_{\mathrm{HH}}=1.5 \mathrm{~Hz}, 2 \mathrm{H}, 4-\mathrm{H}\right), 8.01(8 \mathrm{H}$, 13-H), $7.95(4 \mathrm{H}, 15-\mathrm{H}), 7.90(6 \mathrm{H}, 7-\mathrm{H}, 10-\mathrm{H}), 7.29\left(\mathrm{~d},{ }^{4} J_{\mathrm{HH}}=\right.$ $1.5 \mathrm{~Hz}, 2 \mathrm{H}, 6-\mathrm{H}) .{ }^{13} \mathrm{C}$ NMR $\left(101 \mathrm{MHz}, \mathrm{CD}_{2} \mathrm{Cl}_{2}\right): \delta \mathrm{ppm} 168.04$ $\left(C^{7}\right), 159.76\left(C^{2}\right), 150.53\left(C^{4}\right), 144.51\left(C^{8}\right), 140.73\left(C^{6}\right), 140.39$ $\left(\mathrm{C}^{12}\right), 138.15\left(\mathrm{C}^{11}\right), 133.17\left(\mathrm{C}^{9}\right), 131.95\left(\mathrm{q},{ }^{2} J_{\mathrm{CF}}=33.7 \mathrm{~Hz}, \mathrm{C}^{14}\right)$, $130.16\left(\mathrm{C}^{13}\right), 129.94\left(\mathrm{C}^{10}\right), 123.24\left(\mathrm{q},{ }^{1} J_{\mathrm{CF}}=272.5 \mathrm{~Hz}, \mathrm{C}^{16}\right)$, $121.78\left(\mathrm{C}^{15}\right), 119.33\left(\mathrm{C}^{1}\right), 86.55\left(\mathrm{C}^{5}\right), 80.15\left(\mathrm{C}^{3}\right)$. ES-MS: $\mathrm{m} / \mathrm{z}$ $1742.8\left(\mathrm{M}^{+}\right)$. Anal. Calcd for $\mathrm{C}_{58} \mathrm{H}_{24} \mathrm{~F}_{24} \mathrm{I}_{4} \mathrm{~N}_{2} \mathrm{O}_{2}(M=1744.4 \mathrm{~g}$ $\mathrm{mol}^{-1}$ ): C 39.93, H 1.39, N 1.61. Found: C 41.79, H 1.92, N 1.58.

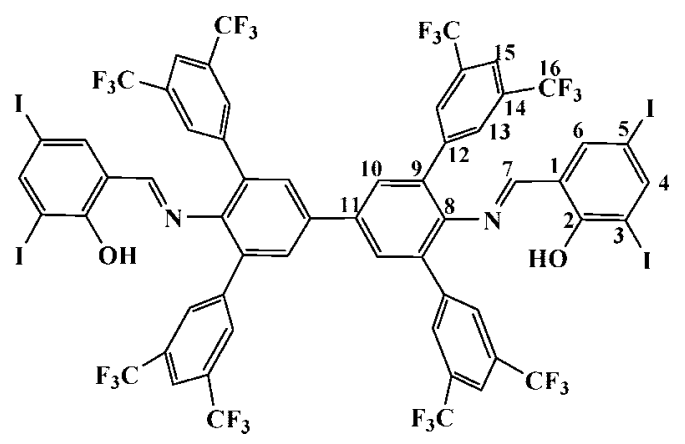

$\left[\mathrm{CH}_{2}\left\{\left(\mathbf{2 , 6}-\left(3,5-\left(\mathrm{CF}_{3}\right)_{2} \mathrm{C}_{6} \mathrm{H}_{3}\right)_{2}-4-\mathrm{yl}-\mathrm{C}_{6} \mathrm{H}_{2}\right)-\mathrm{N}=\mathrm{C}(\mathrm{H})-\left(3,5-\mathrm{I}_{2}-2-\right.\right.\right.$ (OH)- $\left.\left.\mathbf{C}_{6} \mathbf{H}_{2}\right)\right\}_{2}$ ] (11b). Yield: $60 \% .{ }^{1} \mathrm{H}$ NMR $\left(600 \mathrm{MHz}, \mathrm{CD}_{2} \mathrm{Cl}_{2}\right)$ : $\delta /$ ppm $13.01(2 \mathrm{H}, \mathrm{OH}), 8.11(2 \mathrm{H}, 4-\mathrm{H}), 7.93(8 \mathrm{H}, 13-\mathrm{H}), 7.91$ (4 H, 15-H), 7.84 (2 H, 7-H), 7.53 (4 H, 10-H), 7.24 (2 H, 6-H), 4.35 $(2 \mathrm{H}, 17-\mathrm{H}) .{ }^{13} \mathrm{C}$ NMR $\left(151 \mathrm{MHz}, \mathrm{CD}_{2} \mathrm{Cl}_{2}\right): \delta / \mathrm{ppm} 168.32\left(\mathrm{C}^{7}\right)$, $160.06\left(C^{2}\right), 150.65\left(C^{4}\right), 143.56\left(C^{8}\right), 140.90\left(C^{6}\right), 139.81\left(C^{11}\right)$, $132.93\left(\mathrm{C}^{9}\right), 132.14\left(\mathrm{q},{ }^{2} J_{\mathrm{CF}}=34.0 \mathrm{~Hz}, \mathrm{C}^{14}\right), 130.38\left(\mathrm{C}^{13}\right), 130.07$ $\left(\mathrm{C}^{12}\right), 123.54\left(\mathrm{q},{ }^{1} J_{\mathrm{CF}}=272.7 \mathrm{~Hz}, \mathrm{C}^{16}\right), 121.81\left(\mathrm{C}^{15}\right), 119.66\left(\mathrm{C}^{1}\right)$, $86.79\left(\mathrm{C}^{5}\right), 80.34\left(\mathrm{C}^{3}\right), 40.89\left(\mathrm{C}^{17}\right)$. ES-MS: $\mathrm{m} / z$ 1756.4 $\left(\mathrm{M}^{+}\right)$. Anal. 
Calcd for $\mathrm{C}_{59} \mathrm{H}_{26} \mathrm{~F}_{24} \mathrm{I}_{4} \mathrm{~N}_{2} \mathrm{O}_{2}\left(M=1758.43 \mathrm{~g} \mathrm{~mol}^{-1}\right)$ : $\mathrm{C} 40.30, \mathrm{H}$ 1.50, N 1.59. Found: C 39.65, H 1.67, N 1.55.<smiles>Cc1cc(-c2cc([Al]c3cc(C(F)(F)F)cc(C(F)(F)F)c3)cc(-c3cc(C(F)(F)F)cc(C(F)(F)F)c3)c2N=Cc2cc(I)cc(I)c2O)cc(C(F)(F)F)c1</smiles>

[(2,4,6-(3,5-( $\left.\left.\left(\mathrm{CF}_{3}\right)_{2} \mathrm{C}_{6} \mathrm{H}_{3}\right)_{3} \mathrm{C}_{6} \mathrm{H}_{2}\right)-\mathrm{N}=\mathrm{C}(\mathrm{H})-\left(3,5-\mathrm{I}_{2}-2-(\mathrm{OH})-\right.$ $\left.\mathbf{C}_{6} \mathbf{H}_{2}\right)$ ] (12). Yield: $42 \%$. ${ }^{1} \mathrm{H}$ NMR $\left(400 \mathrm{MHz}, \mathrm{CD}_{2} \mathrm{Cl}_{2}\right): \delta / \mathrm{ppm}$ $12.87(1 \mathrm{H}, \mathrm{OH}), 8.1(2 \mathrm{H}, 18-\mathrm{H}), 8.14\left(\mathrm{~d},{ }^{4} J_{\mathrm{HH}}=2.0 \mathrm{~Hz}, 1 \mathrm{H}\right.$, 4-H), 8.04 (1 H, 20-H), 8.01 (4 H, 13-H), 7.96 (2 H, 15-H), 7.90 $(1 \mathrm{H}, 7-\mathrm{H}), 7.85(2 \mathrm{H}, 10-\mathrm{H}), 7.29\left(\mathrm{~d},{ }^{4} J_{\mathrm{HH}}=2.0 \mathrm{~Hz}, 1 \mathrm{H}, 6-\mathrm{H}\right)$. ${ }^{13} \mathrm{C}$ NMR $\left(151 \mathrm{MHz}, \mathrm{CD}_{2} \mathrm{Cl}_{2}\right): \delta / \mathrm{ppm} 168.18\left(\mathrm{C}^{7}\right), 159.78\left(\mathrm{C}^{2}\right)$, $150.63\left(C^{4}\right), 145.15\left(C^{8}\right), 141.36\left(C^{17}\right), 141.05\left(C^{6}\right), 140.17\left(C^{12}\right)$, $137.34\left(\mathrm{C}^{11}\right), 133.33\left(\mathrm{C}^{9}\right), 132.49\left(\mathrm{q},{ }^{2} J_{\mathrm{CF}}=33.6 \mathrm{~Hz}, \mathrm{C}^{19}\right), 132.09$ $\left(\mathrm{q},{ }^{2} J_{\mathrm{CF}}=33.6 \mathrm{~Hz}, \mathrm{C}^{14}\right), 130.18\left(\mathrm{C}^{10}, \mathrm{C}^{13}\right), 129.93\left(\mathrm{C}^{20}\right), 127.50$ $\left(\mathrm{C}^{18}\right), 123.51\left(\mathrm{q},{ }^{1} J_{\mathrm{CF}}=273.2 \mathrm{~Hz}, \mathrm{C}^{21}\right), 123.31\left(\mathrm{q},{ }^{1} J_{\mathrm{CF}}=273.2\right.$ $\left.\mathrm{Hz}, \mathrm{C}^{16}\right), 121.9\left(\mathrm{C}^{15}\right), 119.32\left(\mathrm{C}^{1}\right), 86.79\left(\mathrm{C}^{5}\right), 80.34\left(\mathrm{C}^{3}\right)$. ESMS: $m / z, 1083.9\left(\mathrm{M}^{+}\right)$. Anal. Calcd for $\mathrm{C}_{37} \mathrm{H}_{15} \mathrm{~F}_{18} \mathrm{I}_{2} \mathrm{NO}(M=1085.3$ $\left.\mathrm{g} \mathrm{mol}^{-1}\right)$ : C 40.95, H 1.39, N 1.29. Found: C 41.30, H 1.74, N 1.48 .

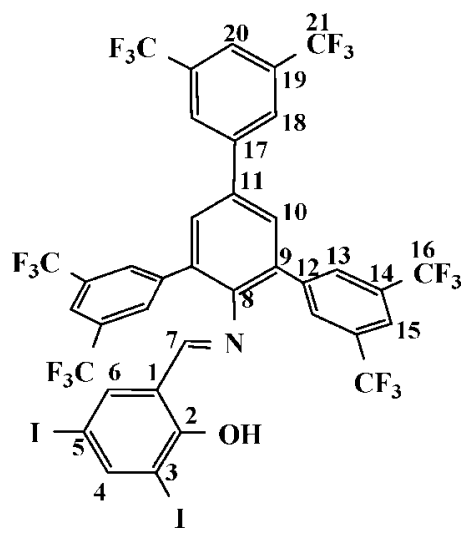

Synthesis of Complexes. [ $\mathrm{CH}_{2}\left\{\left[\left(2,6^{-}{ }^{i} \mathrm{Pr}_{2}-4-\mathrm{yl}-\mathrm{C}_{6} \mathrm{H}_{2}\right)-\mathrm{N}=\mathrm{C}(\mathrm{H})-\right.\right.$ $\left.\left(3,5-\mathrm{I}_{2}-2-\mathrm{O}-\mathrm{C}_{6} \mathrm{H}_{2}\right)-\kappa^{2}-\mathrm{N}, \mathrm{O}\right] \mathrm{Ni}\left(\mathrm{CH}_{3}\right)$ (pyridine) $\left.\}_{2}\right](\mathbf{1 3 b})$. A solution of salicylaldimine $\mathbf{1 0 b}(0.5 \mathrm{mmol})$ in $10 \mathrm{~mL}$ of toluene was added dropwise to a solution of $\left[(\text { tmeda }) \mathrm{Ni}\left(\mathrm{CH}_{3}\right)_{2}\right]^{25}(1.0 \mathrm{mmol})$ in 15 $\mathrm{mL}$ of toluene at $-30{ }^{\circ} \mathrm{C}$. One milliliter of pyridine was added. The reaction mixture was warmed to $0{ }^{\circ} \mathrm{C}$ over the course of $4 \mathrm{~h}$ with stirring. After filtering over diatomaceous earth, the solvent was removed in vacuo, and the orange residue was washed twice with cold pentane, to afford $\mathbf{1 3 b}$ in $91 \%$ yield. ${ }^{1} \mathrm{H}$ NMR $(400 \mathrm{MHz}$, $\left.\mathrm{CD}_{2} \mathrm{Cl}_{2}\right): \delta / \mathrm{ppm} 8.88\left(\mathrm{~d},{ }^{3} J_{\mathrm{HH}}=5.1 \mathrm{~Hz}, 4 \mathrm{H}, 13-\mathrm{H}\right), 7.95\left(\mathrm{~d},{ }^{4} J_{\mathrm{HH}}\right.$ $=2.2 \mathrm{~Hz}, 2 \mathrm{H}, 4-\mathrm{H}), 7.70$ (br, $4 \mathrm{H}, 14-\mathrm{H}), 7.48(2 \mathrm{H}, 7-\mathrm{H}), 7.30$ $\left(\mathrm{d},{ }^{4} J_{\mathrm{HH}}=2.2 \mathrm{~Hz}, 2 \mathrm{H}, 6-\mathrm{H}\right), 7.25\left(\mathrm{t},{ }^{3} J_{\mathrm{HH}}=6.7 \mathrm{~Hz}, 2 \mathrm{H}, 15-\mathrm{H}\right)$, $6.92(4 \mathrm{H}, 10-\mathrm{H}), 3.94(2 \mathrm{H}, 18-\mathrm{H}), 3.88\left(\mathrm{sept},{ }^{3} J_{\mathrm{HH}}=6.8 \mathrm{~Hz}, 4\right.$ $\mathrm{H}, 16-\mathrm{H}), 1.40,1.06\left(\mathrm{~d},{ }^{3} J_{\mathrm{HH}}=6.8 \mathrm{~Hz}, 24 \mathrm{H}, 17-\mathrm{H}, 17^{\prime}-\mathrm{H}\right),-1.07$ $(6 \mathrm{H}, 12-\mathrm{H}) .{ }^{13} \mathrm{C}$ NMR $\left(151 \mathrm{MHz}, \mathrm{CD}_{2} \mathrm{Cl}_{2}\right): \delta / \mathrm{ppm} 164.89\left(\mathrm{C}^{7}\right)$, $163.16\left(C^{2}\right), 152.14\left(C^{13}\right), 148.55\left(C^{4}\right), 146.94\left(C^{8}\right), 141.78\left(C^{9}\right)$, $140.30\left(\mathrm{C}^{11}\right), 138.75\left(\mathrm{C}^{18}\right), 136.79\left(\mathrm{C}^{14}\right), 123.77\left(\mathrm{C}^{10}\right), 123.52$ $\left(\mathrm{C}^{14}\right), 120.49\left(\mathrm{C}^{1}\right), 96.05\left(\mathrm{C}^{5}\right), 71.74\left(\mathrm{C}^{3}\right), 28.10\left(\mathrm{C}^{16}\right), 24.50,22.57$ $\left(\mathrm{C}^{17}, \mathrm{C}^{17^{\prime}}\right),-7.54\left(\mathrm{C}^{12}\right)$. Anal. Calcd for $\mathrm{C}_{51} \mathrm{H}_{56} \mathrm{I}_{4} \mathrm{~N}_{4} \mathrm{Ni}_{2} \mathrm{O}_{2}(M=$

(25) Kaschube, W.; Poerschke, K. R.; Wilke, G. J. Organomet. Chem. 1988, 355, 525-532.
$1382.02 \mathrm{~g} \mathrm{~mol}^{-1}$ ): $\mathrm{C} 44.32, \mathrm{H} \mathrm{4.08,} \mathrm{N} \mathrm{4.05.} \mathrm{Found:} \mathrm{C} 44.72, \mathrm{H}$ $4.10, \mathrm{~N} 4.55$.

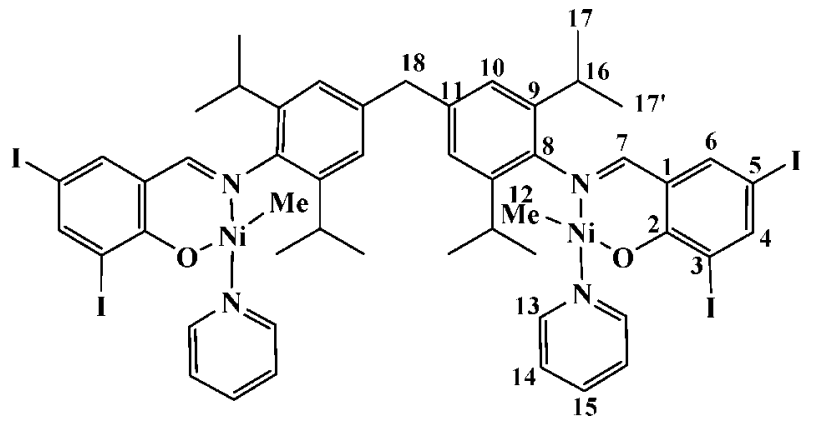

General Procedure for Complex Synthesis from [(pyridine $)_{2}$ $\mathrm{NiMe}_{2}$ ]. [(pyridine $)_{2} \mathrm{NiMe}_{2}$ ] $(248 \mathrm{mg}, 1.0 \mathrm{mmol})$ and the salicylaldimine $(0.51 \mathrm{mmol})$ were weighed into a Schlenk flask and suspended in $20 \mathrm{~mL}$ of diethyl ether at $-30{ }^{\circ} \mathrm{C}$. The reaction mixture changed to a dark red color and an orange precipitate formed, while being warmed to $0{ }^{\circ} \mathrm{C}$ under stirring over the course of $4 \mathrm{~h}$. The solvent was removed in vacuo, and the orange-red residue was washed twice with cold pentane.

$\left[\left\{\left[\left(2,6-{ }^{i} \mathrm{Pr}_{2}-4-\mathrm{yl}-\mathrm{C}_{6} \mathrm{H}_{2}\right)-\mathrm{N}=\mathrm{C}(\mathrm{H})-\left(3,5-\mathrm{I}_{2}-2-\mathrm{O}-\mathrm{C}_{6} \mathrm{H}_{2}\right)-\kappa^{2}-\right.\right.\right.$ $\mathrm{N}, \boldsymbol{O}] \mathrm{Ni}\left(\mathrm{CH}_{3}\right)$ (pyridine) $\}_{2}$ ] (13a). Yield: $80 \% .{ }^{1} \mathrm{H}$ NMR $(600 \mathrm{MHz}$, $\left.\mathrm{C}_{6} \mathrm{D}_{6}\right): \delta / \mathrm{ppm} 8.63(\mathrm{br}, 4 \mathrm{H}, 13-\mathrm{H}), 8.12(2 \mathrm{H}, 4-\mathrm{H}), 7.65(4 \mathrm{H}$, 10-H), 7.26 (2 H, 7-H), 7.18 (2 H, 6-H), 6.68 (2 H, 15-H), 6.33 (4 $\mathrm{H}, 14-\mathrm{H}), 4.13$ (sept, $\left.{ }^{3} J_{\mathrm{HH}}=6.6 \mathrm{~Hz}, 4 \mathrm{H}, 16-\mathrm{H}\right), 1.57,1.06(\mathrm{~d}$, $\left.{ }^{3} J_{\mathrm{HH}}=6.6 \mathrm{~Hz}, 24 \mathrm{H}, 17-\mathrm{H}\right),-0.57(6 \mathrm{H}, 12-\mathrm{H}) .{ }^{13} \mathrm{C} \mathrm{NMR}(151$ $\left.\mathrm{MHz}, \mathrm{C}_{6} \mathrm{D}_{6}\right): \delta / \mathrm{ppm} 165.67\left(\mathrm{C}^{7}\right), 164.09\left(\mathrm{C}^{2}\right), 152.33\left(\mathrm{C}^{13}\right), 149.40$ $\left(C^{4}\right), 149.06\left(C^{8}\right), 142.06\left(C^{6}\right), 141.45\left(C^{9}\right), 140.87\left(C^{11}\right), 136.18$ $\left(\mathrm{C}^{14}\right), 123.21\left(\mathrm{C}^{15}\right), 122.94\left(\mathrm{C}^{10}\right), 120.87\left(\mathrm{C}^{1}\right), 97.48\left(\mathrm{C}^{5}\right), 72.78$ $\left(\mathrm{C}^{3}\right), 28.79\left(\mathrm{C}^{16}\right), 24.92,23.20\left(\mathrm{C}^{17}\right),-6.19\left(\mathrm{C}^{12}\right)$. Anal. Calcd for $\mathrm{C}_{50} \mathrm{H}_{56} \mathrm{I}_{4} \mathrm{~N}_{4} \mathrm{Ni}_{2} \mathrm{O}_{2}\left(M=1367.99 \mathrm{~g} \mathrm{~mol}^{-1}\right)$ : C 43.90, H 3.98, N 4.10. Found: C 44.46, H 4.31, N 4.54.

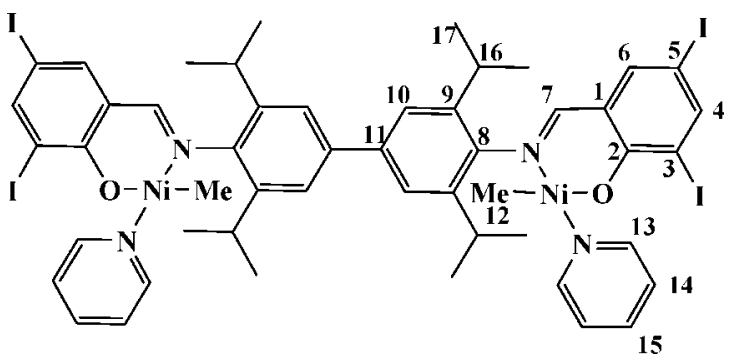

$\left[\left\{\left[\left(2,6-\left(3,5-\left(\mathrm{CF}_{3}\right)_{2} \mathrm{C}_{6} \mathrm{H}_{3}\right)_{2}-4-\mathrm{yl}-\mathrm{C}_{6} \mathrm{H}_{2}\right)-\mathrm{N}=\mathrm{C}(\mathrm{H})-\left(3,5-\mathrm{I}_{2}-2-\mathrm{O}-\mathrm{C}_{6} \mathrm{H}_{2}\right)-\right.\right.\right.$ $\left.\kappa^{2}-N, O\right] N i\left(\mathbf{C H}_{3}\right)$ (pyridine) $\left.\}_{2}\right]$ (14a). Yield: $90 \%$. ${ }^{1} \mathrm{H}$ NMR $(400$ $\mathrm{MHz}, \mathrm{CD}_{2} \mathrm{Cl}_{2}$ ): $\delta / \mathrm{ppm} 8.38\left(\mathrm{~d},{ }^{3} J_{\mathrm{HH}}=5 \mathrm{~Hz}, 4 \mathrm{H}, 13-\mathrm{H}\right), 8.29(8$ $\mathrm{H}, 17-\mathrm{H}), 8.02(4 \mathrm{H}, 19-\mathrm{H}), 7.88\left(\mathrm{~d},{ }^{4} J_{\mathrm{HH}}=2.1 \mathrm{~Hz}, 4 \mathrm{H}, 4-\mathrm{H}\right)$, 7.76 (2 H, 10-H), 7.65 (br, $2 \mathrm{H}, 15-\mathrm{H}), 7.50$ (2H, 7-H), 7.16 (br, 4 $\mathrm{H}, 14-\mathrm{H}), 7.08\left(\mathrm{~d},{ }^{4} J_{\mathrm{HH}}=2.1 \mathrm{~Hz}, 2 \mathrm{H}, 6-\mathrm{H}\right),-0.95(6 \mathrm{H}, 12-\mathrm{H})$. ${ }^{13} \mathrm{C}$ NMR (151 MHz, $\left.\mathrm{CD}_{2} \mathrm{Cl}_{2}\right): \delta / p p m 167.09\left(\mathrm{C}^{7}\right), 163.61\left(\mathrm{C}^{2}\right)$, $151.39\left(\mathrm{C}^{13}\right), 149.73\left(\mathrm{C}^{8}, \mathrm{C}^{4}\right), 141.56\left(\mathrm{C}^{6}\right), 140.78\left(\mathrm{C}^{16}\right), 138.07$ $\left(\mathrm{C}^{11}\right), 137.00\left(\mathrm{C}^{15}\right), 134.14\left(\mathrm{C}^{9}\right), 131.75\left(\mathrm{q},{ }^{2} J_{\mathrm{CF}}=33.5 \mathrm{~Hz}, \mathrm{C}^{18}\right)$, $130.57\left(\mathrm{C}^{17}\right), 129.64\left(\mathrm{C}^{10}\right), 123.81\left(\mathrm{q},{ }^{1} J_{\mathrm{CF}}=273.22 \mathrm{~Hz}, \mathrm{C}^{20}\right)$, $123.60\left(\mathrm{C}^{14}\right), 121.82\left(\mathrm{C}^{19}\right), 119.57\left(\mathrm{C}^{1}\right), 96.45\left(\mathrm{C}^{5}\right), 72.32\left(\mathrm{C}^{3}\right)$, $-7.69\left(\mathrm{C}^{12}\right)$. Anal. Calcd for $\mathrm{C}_{70} \mathrm{H}_{38} \mathrm{~F}_{24} \mathrm{I}_{4} \mathrm{~N}_{4} \mathrm{Ni}_{2} \mathrm{O}_{2}(M=2048.04 \mathrm{~g}$ $\left.\mathrm{mol}^{-1}\right)$ : C 41.02, H 1.87, N 2.74. Found: C 41.21, H 2.21, N 2.91.

$\left[\mathrm{CH}_{2}\left\{\left[\left(2,6-\left(3,5-\left(\mathrm{CF}_{3}\right)_{2} \mathrm{C}_{6} \mathrm{H}_{3}\right)_{2}-4-\mathrm{yl}-\mathrm{C}_{6} \mathrm{H}_{2}\right)-\mathrm{N}=\mathrm{C}(\mathrm{H})-\left(3,5-\mathrm{I}_{2}-2-\mathrm{O}-\right.\right.\right.\right.$ $\left.\left.\mathrm{C}_{6} \mathrm{H}_{2}\right)-\kappa^{2}-N, O\right] N i\left(\mathbf{C H}_{3}\right)$ (pyridine) $\left.\}_{2}\right](\mathbf{1 4 b})$. Yield: $82 \% .{ }^{1} \mathrm{H}$ NMR $\left(600 \mathrm{MHz}, \mathrm{CD}_{2} \mathrm{Cl}_{2}\right): \delta / \mathrm{ppm} 8.43\left(\mathrm{~d}, J_{\mathrm{HH}}=3.0 \mathrm{~Hz}, 4 \mathrm{H}, 13-\mathrm{H}\right)$, $8.30(8 \mathrm{H}, 17-\mathrm{H}), 8.05(4 \mathrm{H}, 19-\mathrm{H}), 7.93(2 \mathrm{H}, 4-\mathrm{H}), 7.72$ (br, $2 \mathrm{H}$, 15-H), 7.52 (2 H, 7-H), 7.42 (4 H, 10-H), 7.22 (br, 4 H, 14-H), $7.11(2 \mathrm{H}, 6-\mathrm{H}), 4.31(2 \mathrm{H}, 21-\mathrm{H}),-0.98(6 \mathrm{H}, 12-\mathrm{H}) .{ }^{13} \mathrm{C} \mathrm{NMR}$ (151 MHz, $\left.\mathrm{CD}_{2} \mathrm{Cl}_{2}\right)$ : $\delta / \mathrm{ppm} 167.12\left(\mathrm{C}^{7}\right), 163.55\left(\mathrm{C}^{2}\right), 151.40\left(\mathrm{C}^{13}\right)$, $149.63\left(C^{4}\right), 148.42\left(C^{8}\right), 141.54\left(C^{6}\right), 141.00\left(C^{16}\right), 139.32\left(C^{11}\right)$, 


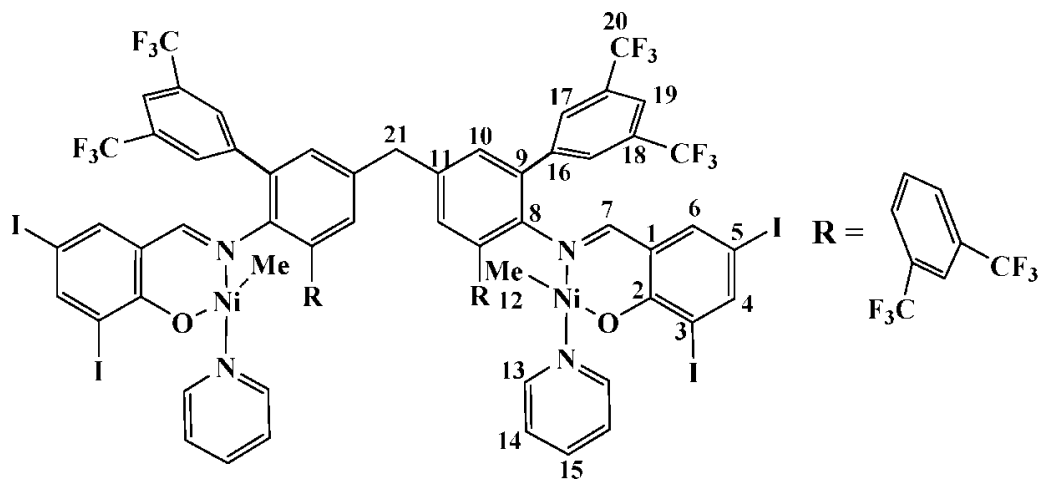

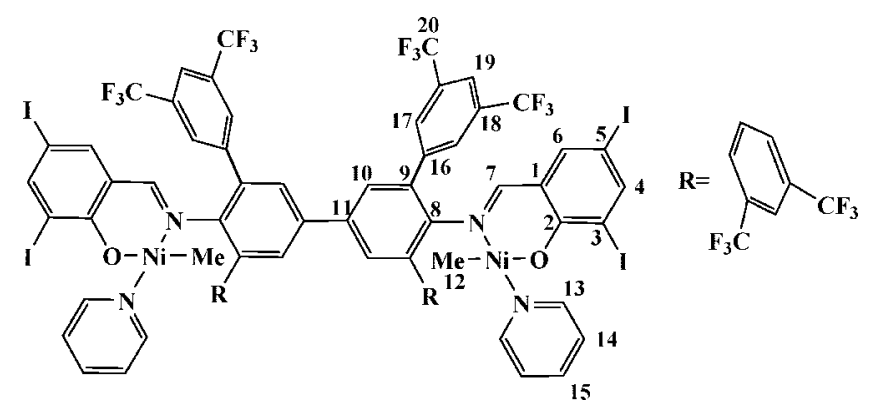

$137.03\left(\mathrm{C}^{15}\right), 133.54\left(\mathrm{C}^{9}\right), 131.66\left(\mathrm{q},{ }^{2} J_{\mathrm{CF}}=32.8 \mathrm{~Hz}, \mathrm{C}^{18}\right), 131.46$ $\left(\mathrm{C}^{10}\right), 130.50\left(\mathrm{C}^{17}\right), 123.68\left(\mathrm{C}^{14}\right), 123.52\left(\mathrm{q},{ }^{1} J_{\mathrm{CF}}=272.9 \mathrm{~Hz}, \mathrm{C}^{20}\right)$, $121.60\left(\mathrm{C}^{19}\right), 119.59\left(\mathrm{C}^{1}\right), 96.38\left(\mathrm{C}^{5}\right), 72.18\left(\mathrm{C}^{3}\right), 40.33\left(\mathrm{C}^{21}\right)$, $-7.93\left(\mathrm{C}^{12}\right)$. Anal. Calcd for $\mathrm{C}_{71} \mathrm{H}_{40} \mathrm{~F}_{24} \mathrm{I}_{4} \mathrm{~N}_{4} \mathrm{Ni}_{2} \mathrm{O}_{2}(M=2062.07 \mathrm{~g}$ $\left.\mathrm{mol}^{-1}\right)$ : C 41.35, H 1.96, N 2.72. Found: C 40.92, H 2.11, N 2.62.

$\left[\left[\left(2,4,6-\left(3,5-\left(C F_{3}\right)_{2} \mathrm{C}_{6} \mathrm{H}_{3}\right)_{3} \mathrm{C}_{6} \mathrm{H}_{2}\right)-\mathrm{N}=\mathrm{C}(\mathrm{H})-\left(3,5-\mathrm{I}_{2}-2-\mathrm{O}-\mathrm{C}_{6} \mathrm{H}_{2}\right)-\right.\right.$ $\left.\kappa^{2}-N, O\right] N i\left(\mathbf{C H}_{3}\right)$ (pyridine)] (17). Yield: $89 \% .{ }^{1} \mathrm{H}$ NMR $(400 \mathrm{MHz}$, $\left.\mathrm{CD}_{2} \mathrm{Cl}_{2}\right): \delta / \mathrm{ppm} 8.42$ (br, $\left.2 \mathrm{H}, 13-\mathrm{H}\right), 8.34(4 \mathrm{H}, 17-\mathrm{H}), 8.15(2 \mathrm{H}$, 22-H), $8.09(2 \mathrm{H}, 19-\mathrm{H}), 7.99\left(\mathrm{~d},{ }^{4} J_{\mathrm{HH}}=2.1 \mathrm{~Hz}, 1 \mathrm{H}, 24-\mathrm{H}\right), 7.92$ (1 H, 4-H), 7.78 (br, $1 \mathrm{H}), 7.69$ (br, $2 \mathrm{H}, 14-\mathrm{H}), 7.55$ (s, $1 \mathrm{H}), 7.20$ (br, $2 \mathrm{H}), 7.14\left(\mathrm{~d},{ }^{4} J_{H H}=2.1 \mathrm{~Hz}, 1 \mathrm{H}\right),-0.91(\mathrm{~s}, 3 \mathrm{H}) .{ }^{13} \mathrm{C} \mathrm{NMR}$ (151 MHz, $\left.\mathrm{CD}_{2} \mathrm{Cl}_{2}\right)$ : $\delta /$ ppm $167.07\left(\mathrm{C}^{7}\right), 163.68\left(\mathrm{C}^{2}\right), 151.41\left(\mathrm{C}^{13}\right)$, $150.37\left(C^{8}\right), 149.85\left(C^{4}\right), 141.61\left(C^{6}\right), 141.40\left(C^{11}\right), 140.57\left(C^{16}\right)$, $137.25\left(\mathrm{C}^{21}\right), 137.10\left(\mathrm{C}^{14}\right), 134.45\left(\mathrm{C}^{9}\right), 132.40\left(\mathrm{~d},{ }^{2} J_{\mathrm{CF}}=33.7\right.$ $\left.\mathrm{Hz}, \mathrm{C}^{23}\right), 131.90\left(\mathrm{q},{ }^{2} J_{\mathrm{CF}}=33.4 \mathrm{~Hz}, \mathrm{C}^{18}\right), 130.58\left(\mathrm{C}^{17}\right), 129.84$ $\left(\mathrm{C}^{10}\right), 127.54\left(\mathrm{C}^{22}\right), 123.76\left(\mathrm{C}^{15}\right), 123.53\left(\mathrm{q},{ }^{1} J_{\mathrm{CF}}=273.3 \mathrm{~Hz}, \mathrm{C}^{20}\right)$, $123.45\left(\mathrm{q},{ }^{1} J_{\mathrm{CF}}=272.0 \mathrm{~Hz}, \mathrm{C}^{25}\right), 121.99\left(\mathrm{C}^{19}\right), 119.55\left(\mathrm{C}^{1}\right), 96.49$ $\left(\mathrm{C}^{5}\right), 72.38\left(\mathrm{C}^{3}\right),-7.70\left(\mathrm{C}^{12}\right)$. Anal. Calcd for $\mathrm{C}_{43} \mathrm{H}_{22} \mathrm{~F}_{18} \mathrm{I}_{2} \mathrm{~N}_{2} \mathrm{NiO}$ $\left(\mathrm{M}=1237.12 \mathrm{~g} \mathrm{~mol}^{-1}\right): \mathrm{C} 41.75, \mathrm{H} 1.79, \mathrm{~N} 2.26$. Found: C 42.17 , H 2.17, N 2.30.

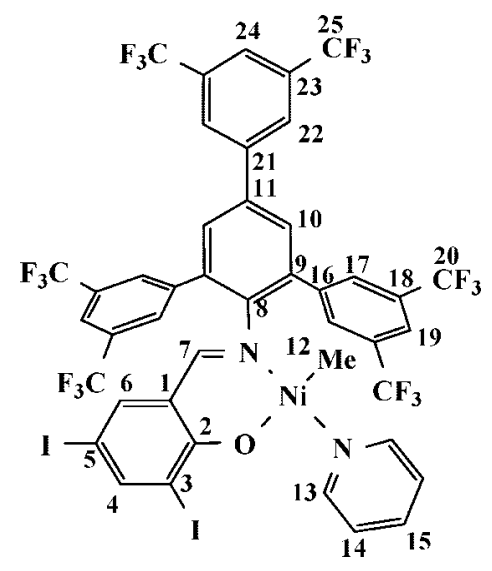

$N, N, N^{\prime}, N^{\prime}$-Tetramethylethylenediamine (tmeda) Complexes. These were prepared analogously to the above general procedure for pyridine complexes, omitting the addition of pyridine. 14atmeda: yield 92\%. Anal. Calcd for $\mathrm{C}_{72} \mathrm{H}_{62} \mathrm{~F}_{24} \mathrm{I}_{4} \mathrm{~N}_{6} \mathrm{Ni}_{2} \mathrm{O}_{2}(M=$
2124.26 $\mathrm{g} \mathrm{mol}^{-1}$ ): C 40.71, H 2.94, N 3.96. Found: C 40.72, H 3.02, N 3.93 .

Polymerizations were carried out in a $1 \mathrm{~L}$ stainless steel mechanically stirred $(500 \mathrm{rpm})$ pressure reactor equipped with a heating/cooling jacket supplied by a thermostat controlled by a thermocouple dipping into the polymerization mixture. A valve controlled by a pressure transducer allowed for applying and keeping up a constant ethylene pressure. The required flow of ethylene, corresponding to ethylene consumed by polymerization, was monitored by a mass flow meter and recorded digitally. Prior to a polymerization experiment, the reactor was heated under vacuum to the desired reaction temperature for 30-60 min and then back-filled with argon.

For nonaqueous polymerizations, $200 \mathrm{~mL}$ of toluene was added to the reactor, and it was flushed with ethylene and stirred under 5 atm of ethylene for $30 \mathrm{~min}$. The catalyst precursor was weighed into a dry syringe in the drybox. The reactor was vented, and in a slight ethylene stream, toluene from the reactor was pulled up into the syringe several times, dissolving and transferring to the reactor the catalyst precursor. The reactor was closed and a constant ethylene pressure was applied. After the desired reaction time the reactor was rapidly vented and cooled to room temperature. The reaction mixture was stirred with $400 \mathrm{~mL}$ of methanol. The polymer was isolated by filtration, washed several times with methanol, and dried in vacuo.

For polymerization in aqueous emulsion, $170 \mathrm{~mL}$ of degassed water was introduced to the reactor and ethylene pressure was applied in order to presaturate the solution. The catalyst precursor was dissolved in $2 \mathrm{~mL}$ of toluene and $0.1 \mathrm{~mL}$ of hexadecane (the latter functions as a hydrophobe). This toluene solution was added to $20 \mathrm{~mL}$ of an aqueous solution of $0.75 \mathrm{~g}$ of SDS. The cooled biphasic mixture was homogenized under an argon atmosphere by means of an ultrasonic homogenizer (Bandelin HD2200 with KE76 tip, operated at $120 \mathrm{~W}, 8 \mathrm{~min}$ ). The resulting miniemulsion was cannula-transferred to the pressure reactor. The pressure reactor was flushed with ethylene, a constant ethylene pressure was then applied, and the reaction mixture was brought rapidly to the desired temperature. After the specified reaction time, the reactor was vented and cooled. A $100 \mathrm{~mL}$ aliquot was precipitated by pouring into $200 \mathrm{~mL}$ of methanol. The polymer was washed three times with methanol and dried in vacuo at $50{ }^{\circ} \mathrm{C}$. The rest of the polymer dispersion was filtered through glass wool.

Acknowledgment. Financial support by BASF AG is gratefully acknowledged. We thank Ralf Thomann (Freiburg) for TEM analyses and Lars Bolk for GPC analyses. S.M. is indebted to the Fonds der Chemischen Industrie and to the Hermann-Schnell Foundation.

Supporting Information Available: Mass flow traces of ethylene uptake during polymerization. This material is available free of charge via the Internet at http://pubs.acs.org. 